\title{
High time resolution boundary layer description using combined remote sensing instruments
}

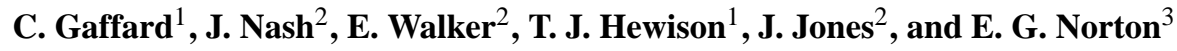 \\ ${ }^{1}$ Met Office, University of Reading, Meteorology Building 1U20, P.O. Box 243, Earley Gate Reading RG6 6BB, UK \\ ${ }^{2}$ Met Office, FitzRoy Road, Exeter, Devon EX1 3PB, UK \\ ${ }^{3}$ University of Manchester, Atmospheric \& Environmental Sciences, Simon Building Manchester M13 9PL, UK
}

Received: 8 October 2007 - Revised: 1 July 2008 - Accepted: 14 July 2008 - Published: 5 September 2008

\begin{abstract}
Ground based remote sensing systems for future observation operations will allow continuous monitoring of the lower troposphere at temporal resolutions much better than every $30 \mathrm{~min}$. Observations which may be considered spurious from an individual instrument can be validated or eliminated when considered in conjunction with measurements from other instruments observing at the same location. Thus, improved quality control of atmospheric profiles from microwave radiometers and wind profilers should be sought by considering the measurements from different systems together rather than individually. In future test bed deployments for future operational observing systems, this should be aided by observations from laser ceilometers and cloud radars. Observations of changes in atmospheric profiles at high temporal resolution in the lower troposphere are presented from a 12 channel microwave radiometer and $1290 \mathrm{MHz}$ UHF wind profiler deployed in southern England during the CSIP field experiment in July/August 2005. The observations chosen were from days when thunderstorms occurred in southern England. Rapid changes near the surface in dry layers are considered, both when rain/hail may be falling from above and where the dry air is associated with cold pools behind organised thunderstorms. Also, short term variations in atmospheric profiles and vertical stability are presented on a day with occasional low cloud, when thunderstorms triggered $50 \mathrm{~km}$ down wind of the observing site Improved quality control of the individual remote sensing systems need to be implemented, examining the basic quality of the underlying observations as well as the final outputs, and so for instance eliminating ground clutter as far as possible from the basic Doppler spectra measurements of the wind profiler. In this study, this was performed manually. The potential of incorporating these types of instruments in future upper air observational networks leads to the challenge
\end{abstract}

Correspondence to: C. Gaffard

(catherine.gaffard@metoffice.gov.uk) to improve the observing systems and also to exploit measurements at high temporal resolution in numerical weather prediction. These examples are intended to inform potential operational users of the changes in atmospheric structure that can be observed with the new types of observing system.

Keywords. Meteorology and atmospheric dynamics (Convective processes; Mesoscale meteorology) - Radio science (Remote sensing)

\section{Introduction}

The aim of the convective storm initiation project (CSIP) in 2005 was to understand the mechanisms responsible for the initiation of precipitating convection in the maritime environment of southern England (Browning et al., 2007). Thunderstorm and rain associated with deep convection are difficult to forecast (Collier, 2007). Such events, responsible for devastating flooding and flash flood are often localised in space and time. For instance, in 2004, a localised rain event of $140 \mathrm{~mm}$ in $5 \mathrm{~h}$ was responsible for a flash flood at Boscastle in Cornwall (Golding, 2005). Adequate representation of this event required the use of high resolution models under development to better represent the deep convection (Lean, 2003).

The Met Office wished to investigate the potential of integrating outputs from various upgraded ground based remote sensing systems when observing summertime boundary layers and the lower troposphere, in an area where convective development is common. This work followed from the integration studies commenced during the TUC field experiment in Switzerland in winter 2003/04 (Klaus et al., 2006). The interpretation of the possible future operational measurements obtained in the boundary layer uses information gathered previously by specialised research instrumentation such as aircraft, tethered balloons and instrumented towers (Young,

Published by Copernicus Publications on behalf of the European Geosciences Union. 
1988; Couvreux et al., 2007). CSIP gave the opportunity of testing how various measurements can be integrated together. CSIP studies were to suggest improved designs and new instrumentation for future operational observational networks, and also improvements in the methods used to assimilate into numerical weather prediction models. This should then lead to improvements in forecasting severe weather.

This paper focuses on analysis of selected events using measurements from a wind profiler and microwave radiometer, collocated at Linkenholt (in central southern England), the UK network of GPS receivers and the UK operational weather radar data. Examples of variations in atmospheric structure at high time resolution, possibly associated with convection are evaluated on 24 and 29 June 2005 and on 25 August 2005. We first present the instrumentation and then show examples of rapid changes in the boundary layer associated with convection either over the observing site or close to the observing site, or downwind of the observing site. Discussions and conclusions from the case studies analyses will indicate whether the high temporal resolution variations observed are significant for future observing requirements. This information will be used in future test bed studies to determine whether the observations can be smoothed over much longer periods with the high temporal resolution measurements considered irrelevant for development of operational numerical weather prediction in future.

\section{Instrumentation}

During the summer of 2005, the Met Office deployed a microwave radiometer, to Manor Farm, Linkenholt (GPS position: $51.19 .05 \mathrm{~N} 1.28 .33 \mathrm{~W} 185 \mathrm{~m}, 19 \mathrm{~km}$ north of Chilbolton research radar, co-located with the wind profiler of the Universities' Facility for Atmospheric Measurement (UFAM).

This study uses observations from the Radiometrics TP/WVP-3000 microwave radiometer (Güldner and Spankuch, 2001), but with a rapid observing cycle to allow the passage of cloud to be resolved for the first time with this type of radiometer in the UK. The radiometer viewed in the zenith direction with very high time resolution $(\sim 12 \mathrm{~s})$. Atmospheric radiances were observed sequentially in 12 channels: seven in the oxygen band $51-59 \mathrm{GHz}$, which provide information primarily on the temperature profile and five between $22-30 \mathrm{GHz}$ near a water vapor line, which provide cloud and humidity profile information. The radiometer system included sensors to measure pressure, temperature and humidity at $\sim 1 \mathrm{~m}$ above the surface. The instrument's integral rain sensor was used to reject periods which may be contaminated by scattering from precipitation, and emission from raindrops on the radome, which may bias the calibration. The radiometer incorporated a recently designed blower to minimize the retention of raindrops on the radome. The radiometer also incorporated a zenith-viewing infrared ra- diometer $(9.6-11.5 \mu \mathrm{m})$ to provide information on the cloud base temperature.

Water vapour channels were calibrated by hourly tip curves, at 5 angles in the North-South plane, except between 11:00-13:00 UTC, when there was a risk of contamination by the Sun. Oxygen band channels were calibrated with liquid nitrogen on 21 June 2005.

All channels also viewed the internal black body target for relative calibration, initially every $5 \mathrm{~min}$. From 23 June to 8 July 2005 a configuration error stopped the internal calibration cycle between 11:00-13:00 UTC and the output from the radiometer became unreliable in this time interval.

Temperature, humidity and liquid profiles were obtained from the microwave brightness temperatures using the manufacturer's neural network retrieval, trained using radiosonde measurements and a radiative transfer model (Solheim, 1998). The accuracy of the retrievals was evaluated against radiosonde measurements (Hewison, 2007), with accuracy decreasing with height from $0.6 \mathrm{~K}$ near the surface to $1.5 \mathrm{~K}$ at $3.3 \mathrm{~km}$ for the temperature profiles and from $0.5 \mathrm{~g} / \mathrm{m}^{3}$ near the surface to $1.1 \mathrm{~g} / \mathrm{m}^{3}$ between $1-2 \mathrm{~km}$ for water vapour. Vertical resolution for temperature measurements for this type of radiometer was estimated to be about half the height from the surface in the region 0 to $3 \mathrm{~km}$, e.g. about $500 \mathrm{~m}$ at $1 \mathrm{~km}$, whilst for water vapour measurements it was around $500 \mathrm{~m}$ from the surface to about $1.5 \mathrm{~km}$, then increasing to about $1 \mathrm{~km}$ at $2.5 \mathrm{~km}$ (Cimini et al., 2006). In practice this means the radiometer would normally identify the existence of a significant temperature inversion below $1 \mathrm{~km}$ but would find difficulty in identifying inversions at heights above $1 \mathrm{~km}$.

The wind profiler deployed with the microwave radiometer was a $1290 \mathrm{MHz}$ UHF pulse Doppler radar system designed by Degreane Horizon. Most of the time, the profiler operated in a single mode, switching sequentially between its 3 beams. The set up of the wind profiler was intended to capture high time resolution events, with a full observation cycle lasting around a minute and a half, much shorter than the cycle used by operational wind profilers in the UK. The wind profiler provided data from $150 \mathrm{~m}$ to $3500 \mathrm{~m}$ above the ground level with a resolution of $150 \mathrm{~m}$ and an overlap between range gates of 50\%. Wind measurements in the first 5 range gates were made possible by attenuating the signal to protect the receiver from leakage from the transmitted pulse, so the signal to noise ratio in these first gates is not compatible with the rest of the range gates. A temporary clutter fence was erected around the wind profiler, but this did not prove very effective at suppressing ground clutter. So, great care has been taken to avoid the use of observations where ground clutter was introducing errors into the wind or signal to noise measurements.

Path delays to GPS satellite signals during propagation through the troposphere to a ground receiver can be used to produce estimates of vertically integrated water vapour (IWV) (Bevis, 1994). The UK GPS data network was processed by the Met Office/University of Nottingham system. 
Here again, the system was set up to provide integrated water amount as often as possible, every fifteen minutes using 15 min centred integration time. Operational plots of GPS water vapour include the positions of cloud to ground lightning strikes detected by the Met Office operational lightning detection system, e.g. see the purple rectangles in Fig. 3e and Fig. 6.

The Met Office operates a network of 12 weather radars. They provide composite images of rainfall rate continuously over UK with a $1 \mathrm{~km}$ to $5 \mathrm{~km}$ grid size resolution depending on the range from the radar. The beam-width is $1^{\circ}$ and the lowest elevation angle can be 0 or $0.5^{\circ}$. The data used in this study were produced every $15 \mathrm{~min}$ and were taken with a 5 min acquisition time.

Radiosondes used in the study were launched from Larkhill and Chilbolton, situated $38 \mathrm{~km}$ south-west and 19 $\mathrm{km}$ south of Linkenholt, respectively.

\section{Rain evaporation boundary layer cooling}

On the 24 June 2005 widespread thunderstorms occurred in southern UK and the Midlands, resulting in a couple of flash floods. The outbreaks were associated with a trough aligned approximately south west to northeast across central southern England, with a cold front located much further to the west over the Irish Sea all day. Early in the morning most of the storms were located in southwest England, and were in the vicinity of Linkenholt from about 06:00 UTC to 14:00 UTC and occurred further east later in the day. Two different conditions will be considered, the first with a very dry layer over Linkenholt, with thunderstorms near but dying out over Linkenholt early in the morning, and the second with a pool of drier air behind an organised line of thunderstorms passing over Linkenholt at 14:00 UTC.

3.1 High temporal resolution atmospheric structures in a very dry boundary layer

Weather radar samples in the morning between 06:15 UTC and 07:15 UTC are shown, see Fig. 3a to d. Radar samples were a combination from the operational weather radar located at Chenies at $85 \mathrm{~km}$ to the east north east and $155 \mathrm{~m}$ above sea level and Warden Hill located about the same distance to the southwest. The lowest layer seen by either radar over Linkenholt at this range would be centred at $900 \mathrm{~m}$ above sea level and was $1.5 \mathrm{~km}$ deep in the vertical and $1.5 \mathrm{~km}$ wide.

One end of a band of lightning activity about $70 \mathrm{~km}$ in length moved north-eastwards just to the west of Linkenholt at about $15 \mathrm{~ms}^{-1}$. This band was aligned approximately from north west to south east at 06:00 UTC, see Fig. 3e and the south eastern end passed near Linkenholt between 06:15 and 06:30 UTC. The storms at the eastern end of the band died out shortly after passing Linkenholt. The lightning ac-
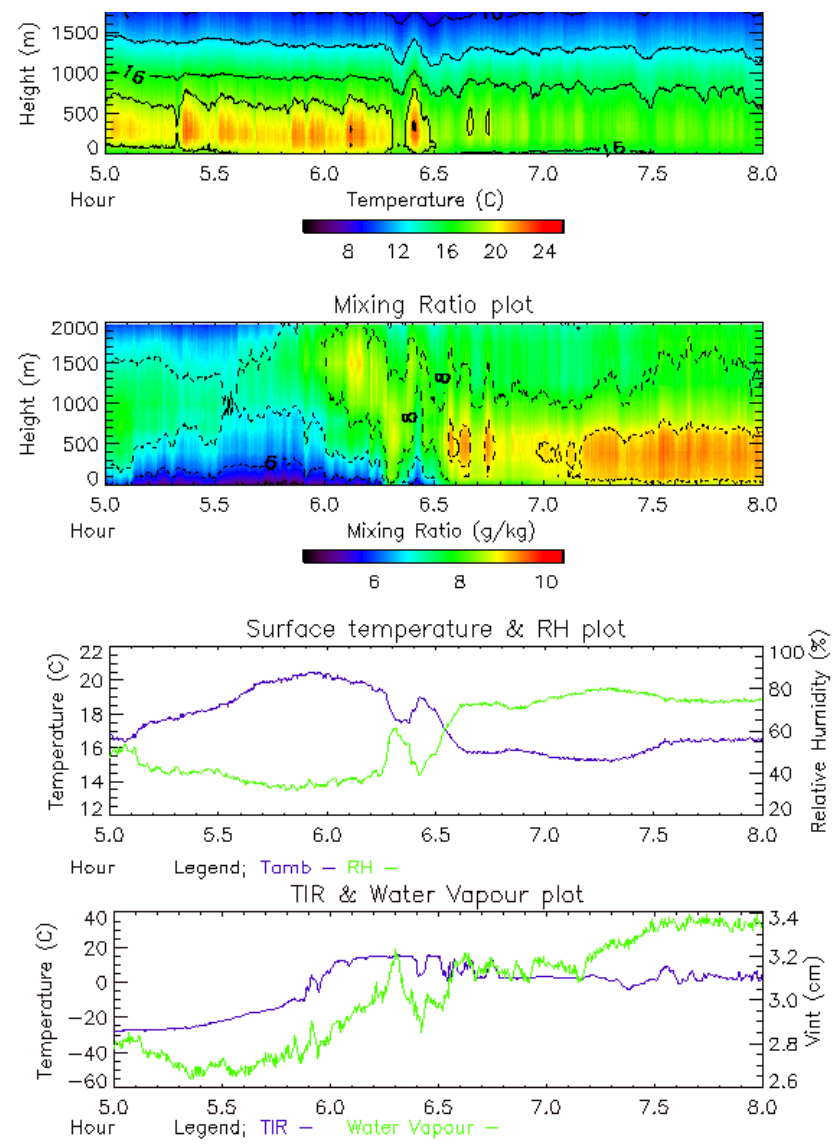

Fig. 1. Microwave radiometer retrieval showing temperature, mass mixing ratio, -height cross sections for $0-2 \mathrm{~km}$ height, 24 June 2005, 05:00-08:00 UTC. Time series of surface temperature and relative humidity, integrated water content and infrared temperature are also shown.

tivity was associated with a number of smaller cells rather than a large area of deep convection. In Fig. 3a lightning strikes were observed from small high intensity cells at about $45 \mathrm{~km}$ and $70 \mathrm{~km}$ to the northwest of Chilbolton (with lightning strikes also observed from the cell about $75 \mathrm{~km}$ to the southwest of Chilbolton). In Fig. $3 b$ the high intensity cell about $25 \mathrm{~km}$ slightly west of north from Linkenholt was the final lightning event at the southeast end of the band of activity. One more strike was detected from the cell about $60 \mathrm{~km}$ to the southeast of the bulls eye in Fig. $3 \mathrm{c}$ and after that no more lightning was detected close to Linkenholt for about $2 \mathrm{~h}$.

The rain $20 \mathrm{~km}$ to the northwest of Linkenholt moved north-eastwards through this period at a regular rate. A small high intensity convective cell of short lifetime occurred within $5 \pm 2 \mathrm{~km}$ of Linkenholt at 06:30 UTC. For the remainder of the time between 06:15 and 06:45 UTC, lower rates of precipitation at $900 \mathrm{~m}$ were detected close to or over Linkenholt with little movement in position of the rain cells. 


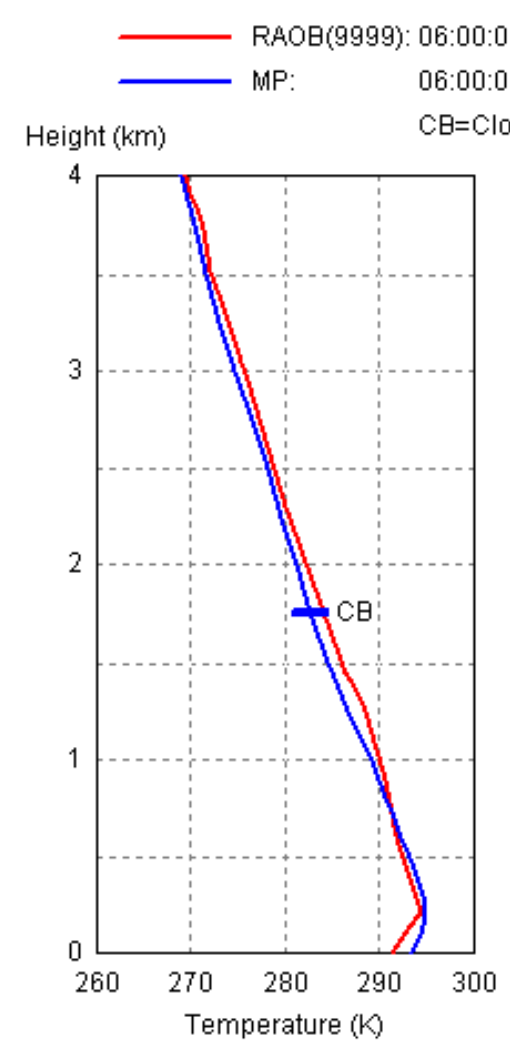

$0600006 / 24 / 05$

Sta Alt: $132 \mathrm{~m}$

Tir: $280.6 \mathrm{~K}$

9гロdiameヒrics

$\mathrm{CB}=\mathrm{Cloud}$ Base

Rain: $N$

Int Vap: $2.84 \mathrm{~cm}$
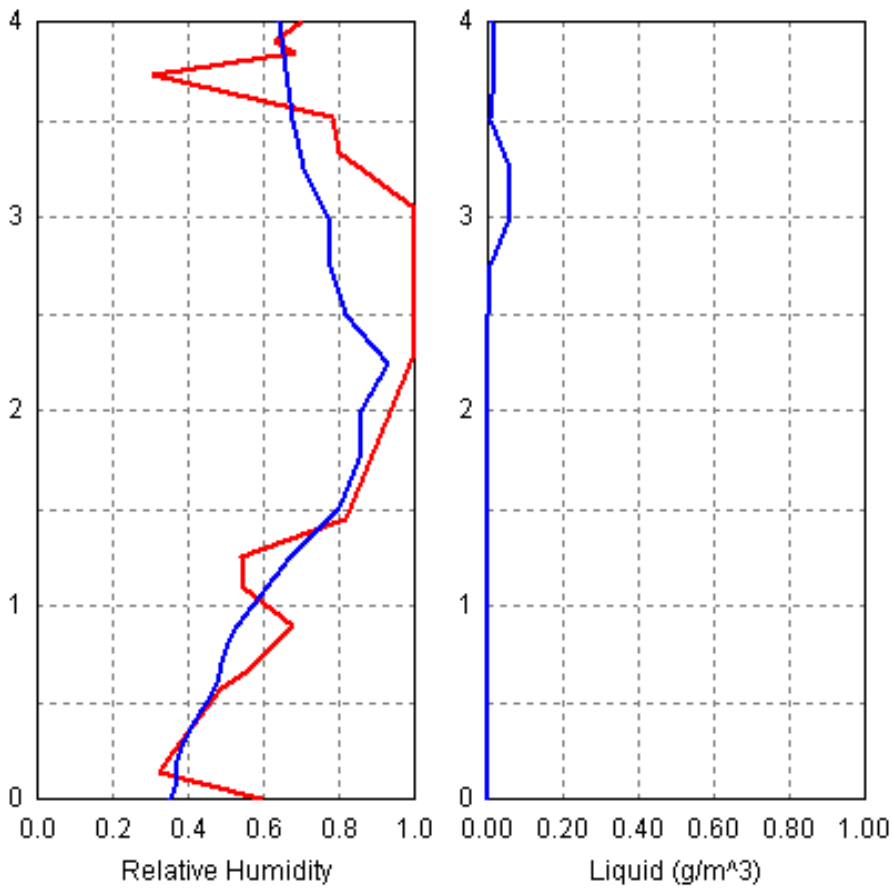

Fig. 2. Atmospheric profiles of temperature, relative humidity and liquid water measured by a radiosonde launched from Larkhill (RAOB, red line) and retrieved by microwave radiometer at Linkenholt (MP, blue line). 6 June 2005, 06:00 UTC.

Figure 1 shows the time height cross section of temperature, mixing ratio profile and surface and infrared measurements and integrated water content between 05:00 UTC and 07:00 UTC as produced by the radiometer. At 05:00 UTC there was a temperature inversion of nearly $5^{\circ}$ with the maximum temperature at $300 \mathrm{~m}$. The maximum temperature in the inversion showed an upward trend in general up to about 06:10 UTC. After this the temperature dropped significantly and then rose again to a final maximum at about 06:30 UTC. The air in the lowest layers mostly cooled between 06:00 and 06:40 UTC when the inversion became less pronounced.

The radiometer observed dry air near the surface at 05:00 (relative humidity 55\%, mixing ratio $6 \mathrm{~g} / \mathrm{kg}$. This lowest air became drier with time until 05:50 UTC (35\%). At 06:19 UTC, the mixing ratio measured by the radiometer at $100 \mathrm{~m}$ increased rapidly to about $8 \mathrm{~g} / \mathrm{kg}$ and then after $6 \mathrm{~min}$ returned to $6 \mathrm{~g} / \mathrm{kg}$ and then finally increased to $8 \mathrm{~g} / \mathrm{kg}$ at 06:30 UTC. The microwave radiometer liquid water measurements indicated cloud overhead between 1 and $2 \mathrm{~km}$ from 06:00 UTC to about 06:40 UTC.

This warm dry air near the surface was also observed by a radiosonde launched at 06:00 UTC at Larkhill about $35 \mathrm{~km}$ to the west from Linkenholt. (Fig. 2). At this time the end of the band of lightning activity was about $50 \mathrm{~km}$ to the west south west of Larkhill. The radiosonde supports the profiles re- ported by the radiometer although the temperature inversion was slightly less sharp at Linkenholt that at Larkhill possibly the result of the poorer vertical resolution of the radiometer measurement. At $200 \mathrm{~m}$ the vertical resolution is at best around $100 \mathrm{~m}$ (Cadeddu, 2002). The GPS IWV measurements suggested that the dry warm layer was also found at this distance inland from the coast at distances up to $150 \mathrm{~km}$ to the east towards London, but not near the south coast.

The wind profiler measurements of wind component $U$ and $V$ and signal to noise ratio can be found in Fig. 4a to c, respectively. Here, wind measurements which are considered doubtful because of range aliasing, anomalies induced by precipitation not observed in three beams or in a side lobe have been greyed out, and also the associated signal to noise. In the lowest $500 \mathrm{~m}$ the winds changed significantly between 06:00 and 07:00 UTC. At 06:00 UTC winds below $500 \mathrm{~m}$ were relatively weak and from the east, so that the air would have been drawn towards the advancing line of thunderstorm activity. At 07:00 UTC winds below $500 \mathrm{~m}$ were from the NNW and about $10 \mathrm{~ms}^{-1}$ so would represent a flow behind and to the south relative to the line of thunderstorm activity. The wind profiler signal to noise is clearly higher in the region of wind shear above the NNW low level winds, suggesting more turbulent mixing than was occurring in the very stable conditions before 06:30 UTC. 


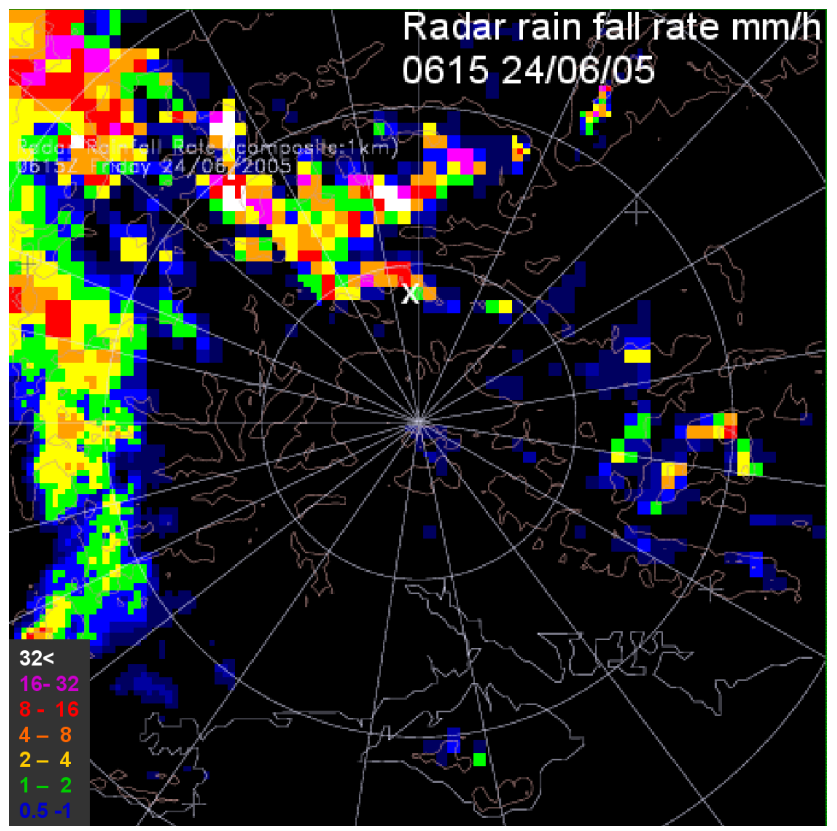

Fig. 3a. Composite weather radar rainfall for the 24 June 2005 at 06:15 UTC. The white cross indicate Linkenholt site. The rain rate/ $\mathrm{h}$ is indicated by the colour scale on the bottom left. The bullseye is centred at the Chilbolton radar with the first and second circles of radius 25 and $50 \mathrm{~km}$.

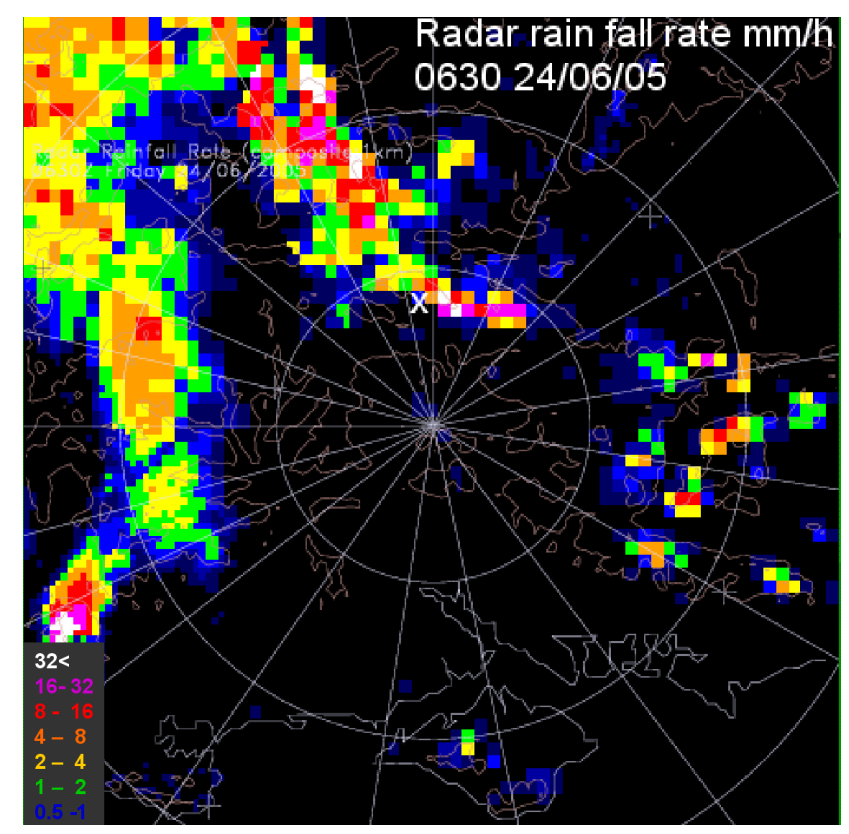

Fig. 3b. Composite weather radar rainfall for the 24 June 2005 at 06:30 UTC. The white cross indicate Linkenholt site. The rain rate/h is indicated by the colour scale on the bottom left. The bullseye is centred at the Chilbolton radar with the first and second circles of radius 25 and $50 \mathrm{~km}$.

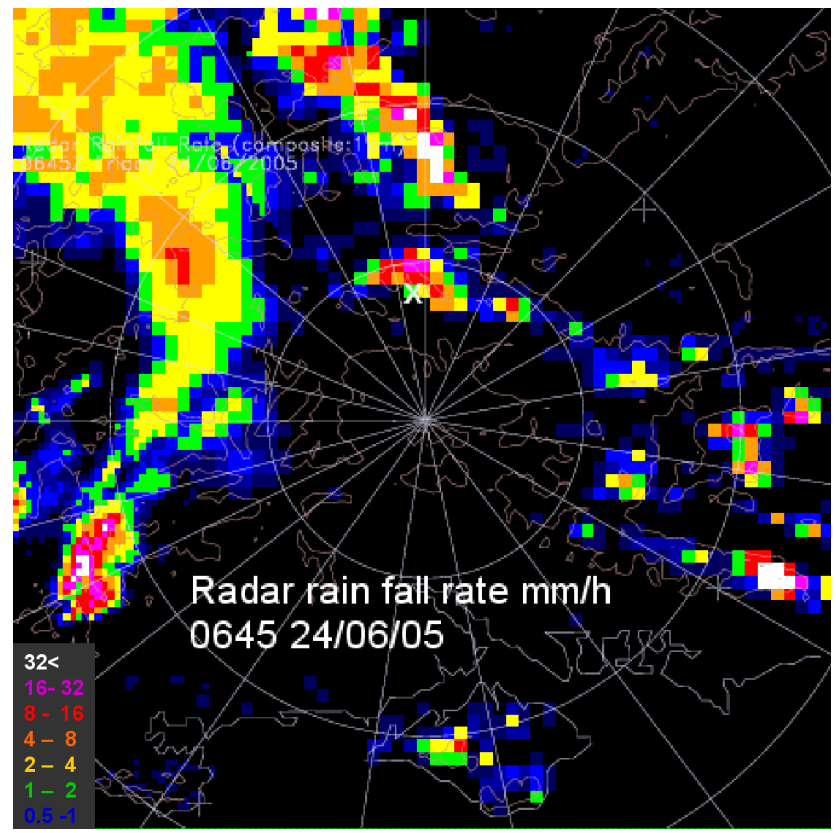

Fig. 3c. Composite weather radar rainfall for the 24 June 2005 at 06:45 UTC. The white cross indicate Linkenholt site. The rain rate/h is indicated by the colour scale on the bottom left. The bullseye is centred at the Chilbolton radar with the first and second circles of radius 25 and $50 \mathrm{~km}$.

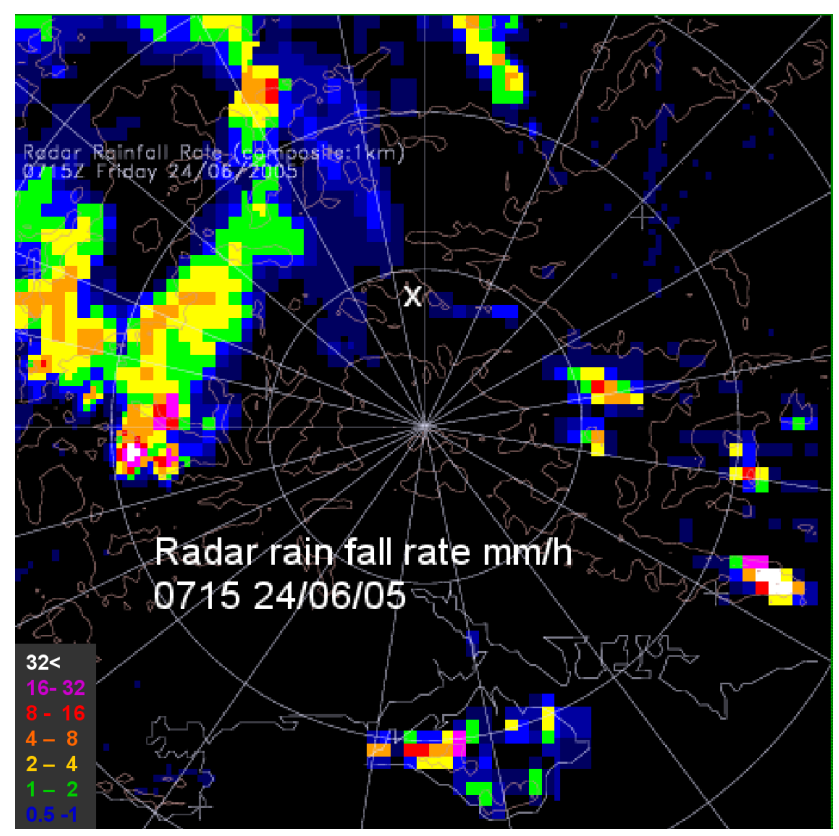

Fig. 3d. Composite weather radar rainfall for the 24 June 2005 at $07: 15$ UTC. The white cross indicate Linkenholt site. The rain rate/ $\mathrm{h}$ is indicated by the colour scale on the bottom left. The bullseye is centred at the Chilbolton radar with the first and second circles of radius 25 and $50 \mathrm{~km}$. 


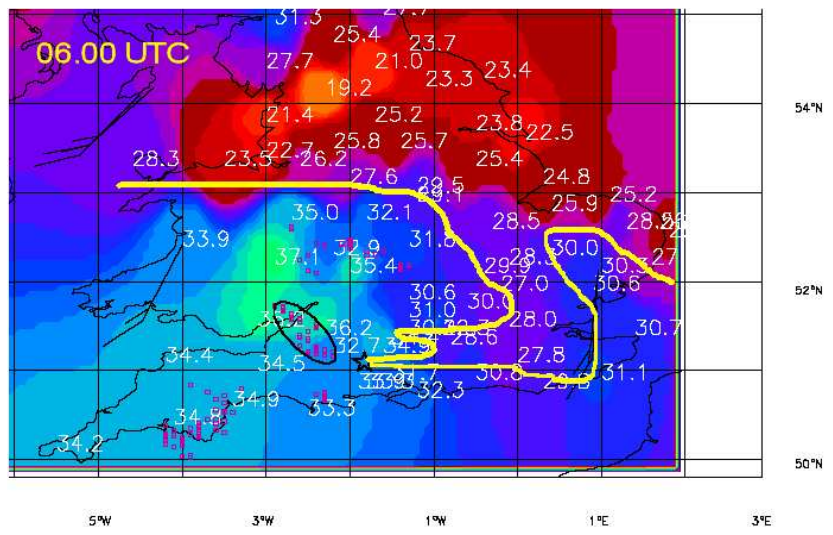

Fig. 3e. GPS integrated water vapour processed by the Met Office/University of Nottingham system, 24 June 2005, 06:00 UTC. Contours for values of IWV in $\mathrm{kg} \mathrm{m}^{-2}$. Yellow contour is the limit of air with less than $30 \mathrm{~kg} \mathrm{~m}^{-2}$ in southern England. Black star is location of Larkhill, black ellipse encloses the lightning activity which passed just to the northwest of Linkenholt. During the day the low values in northern England seemed inversely correlated to the thunderstorm activity in southern and central England.

At about $1.2 \mathrm{~km}$ above the ground there was strong vertical wind shear in the $U$ component between 04:00 UTC and 06:30 UTC and this correlates with a local maximum of signal to noise in the vertical, and could be expected to indicate the layer where there was a relatively strong positive hydro lapse seen in the Larkhill radiosonde at this height.

Before 06:00 UTC, the winds between 2 and $3 \mathrm{~km}$ were typically between 13 and $15 \mathrm{~ms}^{-1}$ from the southwest, and the band of thunderstorm activity was moving at a similar speed. After 07:00 UTC the westerly component at this level reduced to a slight easterly direction, with this change probably taking place around 06:45 UTC and the southerly component may have increased a little in the long term. Thus, although the band of lightning activity was being driven by the winds above $2 \mathrm{~km}$, there was a significant change in very low level winds associated with the passage of the organised band of lightning, and this change was associated with the change in atmospheric conditions near the surface.

The approach of the lower cloud associated with the lightning activity can be seen from the measurements by the infrared radiometer on the microwave radiometer, see Fig. 1, which indicate a cloud base at around $1.5 \mathrm{~km}$ had arrived by 06:10 UTC.

Then the temperature at $1 \mathrm{~m}$ above the ground started to decrease slowly by $1^{\circ} \mathrm{C}$ in $9 \mathrm{~min}$ from $20.6^{\circ} \mathrm{C}$ and this was followed at 06:19 UTC, by a sudden drop of temperature ( $1.8^{\circ}$ in less than $2 \mathrm{~min}$ ), associated with a sudden increase in relative humidity of 20 per cent. At the same time the integrated water vapour measured by the microwave radiometer increased from 30 to $32 \mathrm{~kg} \mathrm{~m}^{-2}$ and the microwave radiometer indicated that temperatures fell by similar amounts between the surface and $1.25 \mathrm{~km}$. the temperature inversion weakened, and the humidity profile showed higher relative humidity from the surface to $1 \mathrm{~km}$. 8 min later the surface temperature recovered by about $1.5^{\circ} \mathrm{C}$ and the relative humidity had reduced by about 17 per cent. After this the transition associated with the change in direction of the lowest winds took place and by 06:33 UTC, surface temperature had dropped to $15.8^{\circ} \mathrm{C}$ and relative humidity had risen to near $72 \%$. The rain sensor on the radiometer did not indicate rain reaching the surface, and in fact did not show any increase in voltage, so it is concluded that no rain was reaching the radiometer and corrupting its measurements.

The effect of rain on the wind profiler measurements was checked in detail using the Doppler Spectra. Doppler spectra with double peaks indicated either range aliasing in the vertical, heavy rain in the beam or heavy rain in a side lobe to the side of the profiler and radiometer. Double spectra were found for some heights at times between 06:20 and 06:31 UTC, within the times when stronger signals were observed above $2 \mathrm{~km}$ in Fig. 4c. So the sudden drop in surface temperature occurred just before the precipitation was observed at $2 \mathrm{~km}$, i.e. just preceding the active part of the end of the band of lightning.

Figure 4d shows Doppler spectra from the vertical beam of the wind profiler (stacked as a function of height) corresponding to the 45 gates of the low mode for 06:23 UTC. The spectra are plotted using a logarithmic scale. The vertical speed measured by the wind profiler was heavily contaminated by ground clutter at this period, probably due to the existence of the dry layer near the surface, with the atmospheric signals very low compared to the ground clutter. The signature of raindrops, falling with a vertical speed of between 2 and $3 \mathrm{~ms}^{-1}$, is quite clear down to $820 \mathrm{~m}$. These average fall speeds would be associated with relatively weak rainfall. At $595 \mathrm{~m}$ it is possible that limited numbers of drops are still contributing to the signal since the spectrum is skewed toward positive values.

Above $1420 \mathrm{~m}$, the double structure of the spectra may be due to range aliasing from precipitation at high levels above $7 \mathrm{~km}$ (requiring very much stronger signals from heights at around $7 \mathrm{~km}$ ) or from heavier rain observed in a side lobe. This gives supporting evidence for more intense convection occurring near Linkenholt, but not directly over the wind profiler and radiometer, as shown by the weather radar.

Lidar and cloud radar measurements at Chilbolton (see Fig. 9 for cloud radar) showed strong cloud returns at heights above 5 and $7 \mathrm{~km}$ during this period, so range aliasing could have occurred, as could the very strong signals in side lobes.

Thus, the sudden drop of the temperature seen by the radiometer system seems real and was possibly due to air in a gust front that had been cooled by evaporation of precipitation, possibly as the strong convection developed close by. The wind profiler measurements at $700 \mathrm{~m}$ at 06:20 UTC indicate a relatively weak northwest wind $\left(4 \mathrm{~ms}^{-1}\right)$, and no winds were reported at low level because the Doppler spectra were very much broader than usual. By 06:30 UTC the 


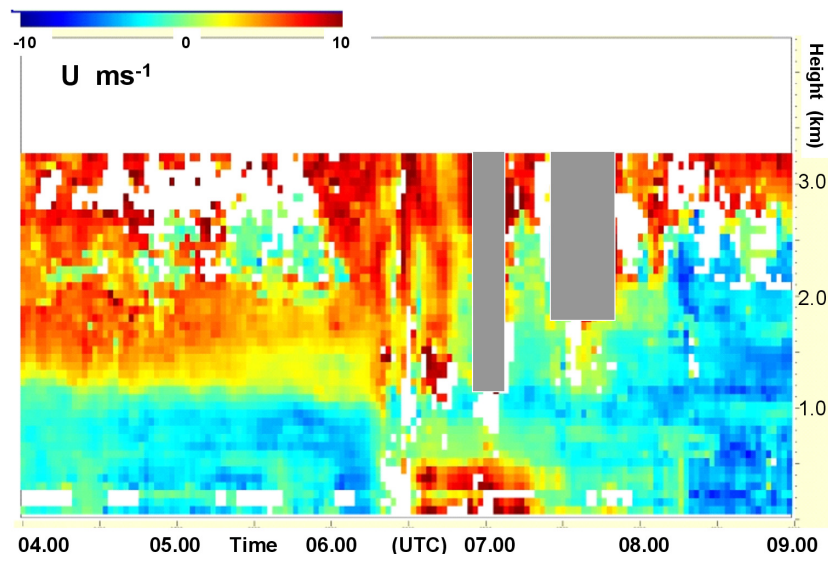

Fig. 4a. Wind $U$ component measured by the wind profiler at Linkenholt 24 June 2005, 04:00 to 09:00 UTC from 75 to $3250 \mathrm{~m}$ a.g.1.

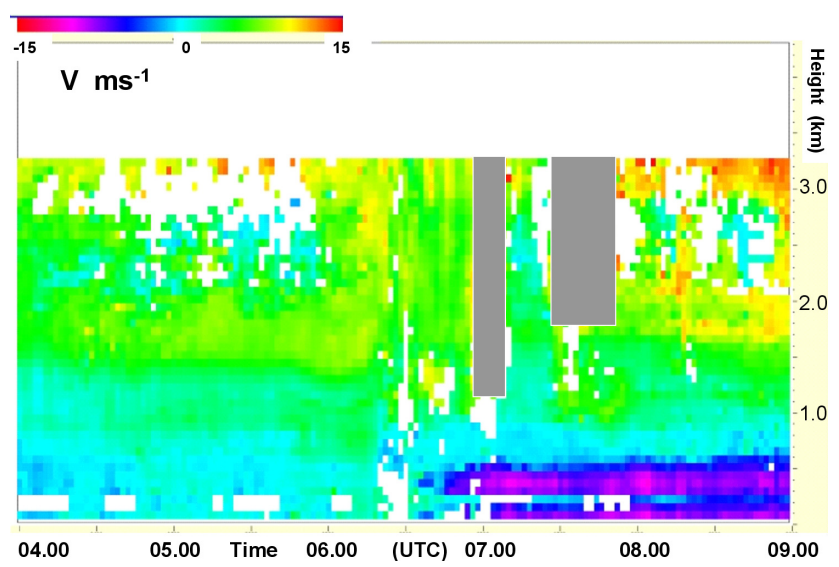

Fig. 4b. Wind $V$ component measured by the wind profiler at Linkenholt 24 June 2005, 04:00 to 09:00 UTC from 75 to $3250 \mathrm{~m}$ a.g.1.

surface temperature dropped permanently and the very dry layer disappeared. This was due to a change in the air being advected over Linkenholt, since the wind direction and speed observed by the wind profiler changed significantly at 06:30 UTC. By 07:15 UTC, the weather radar shows that all the showers in the area (Fig. 4d) had vanished, with no short term convection present any longer. So it can be seen that the microwave radiometer system was able to measure detailed changes in the lowest layers of the boundary layer, associated with the colder pools of air generated by rainfall evaporation into very dry air, as well as with the change of air mass which led to a temporary respite in thunderstorm activity. These variations would not have been taken seriously, without the supporting evidence from the other observing systems.

With respect to deploying observing systems in future for this type of experiment or operation, the problems in identifying range aliasing show that although detailed measure-

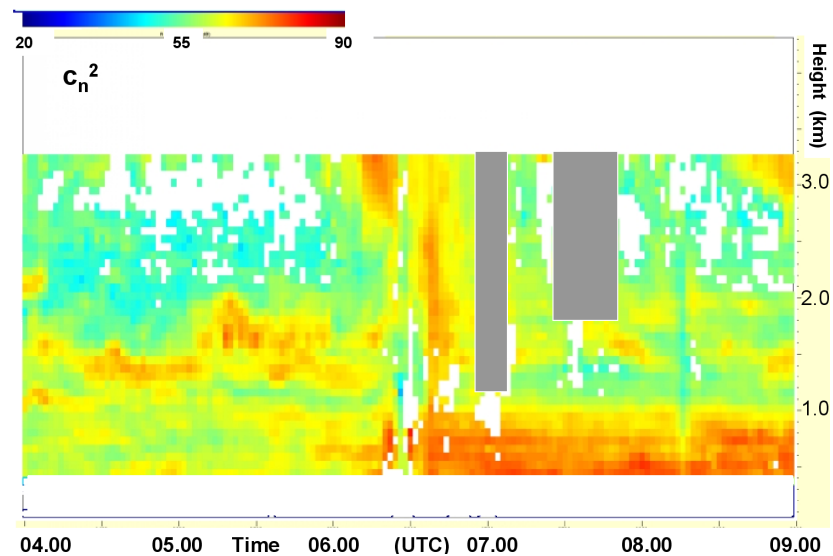

Fig. 4c. Range corrected signal to noise ratio in $\mathrm{dB}$ measured by the wind profiler at Linkenholt 24 June 2005, 04:00 to 09:00 UTC from 75 to $3250 \mathrm{~m}$ a.g.1.

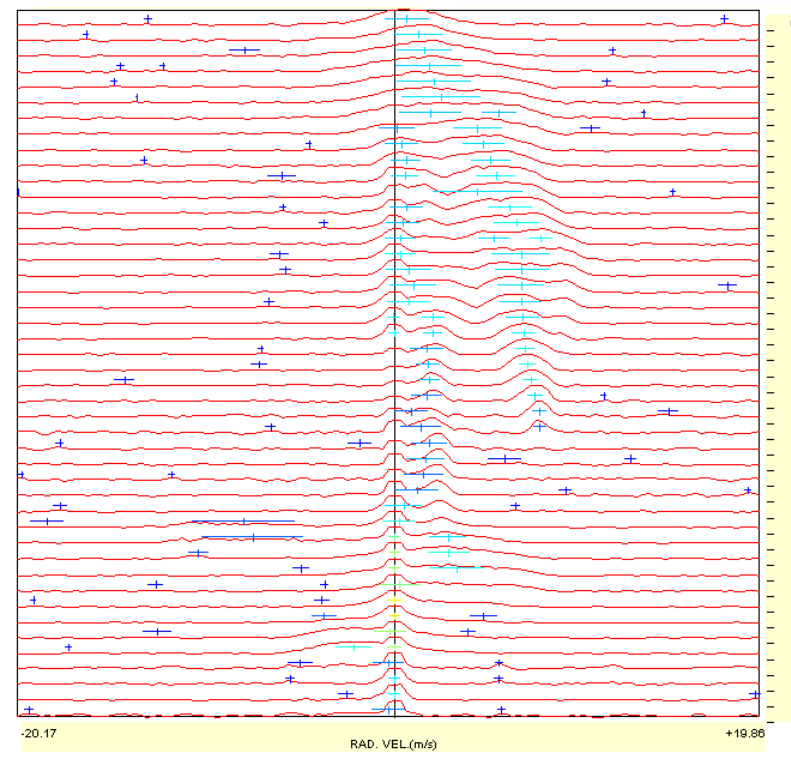

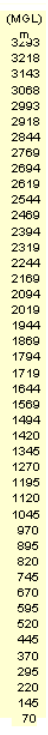

Fig. 4d. Stacked as a function of height of Doppler spectra from the vertical beam corresponding to the 45 gate of the low mode for 06:23 UTC. The height of the gate above the ground level is indicated on the y-axis, The Doppler velocity on $\mathrm{x}$-axis. Each spectrum is plotted using a logarithmic scale for the power. Positive velocity is for motion towards the wind profiler.

ments in the boundary layer are a priority it is also necessary to operate the wind profiler with an interleaved high mode that can observe up to $8 \mathrm{~km}$ at least, which would allow better quality control of the low level measurements.

3.2 Characteristics of cold pool associated with an organised line of thunderstorms

In the early afternoon an organised line of thunderstorms aligned north south crossed the entire CSIP observation 


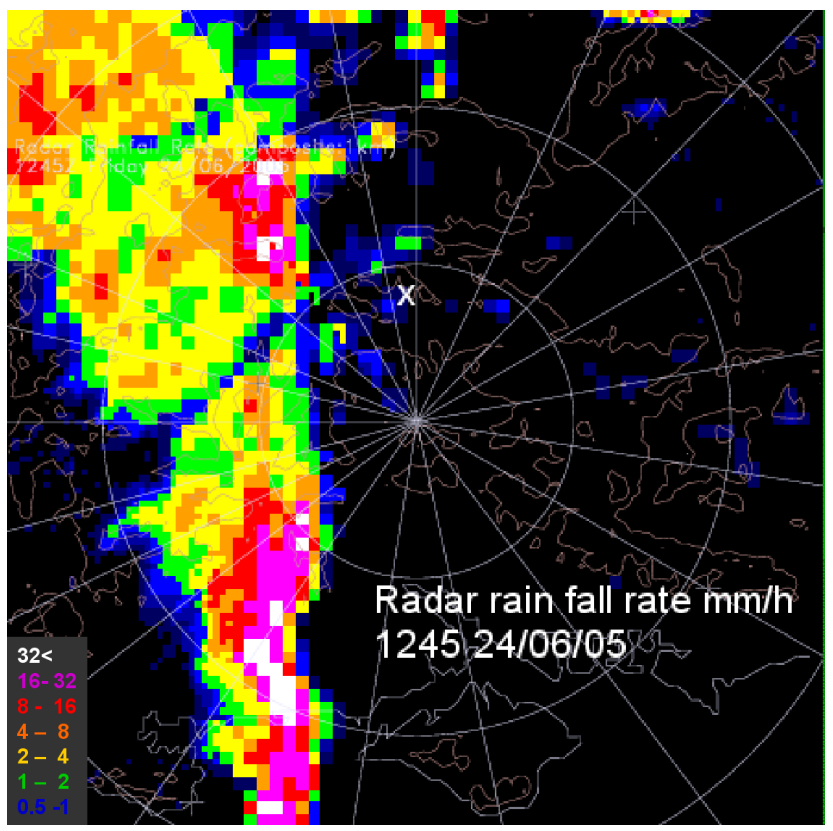

Fig. 5a. Composite weather radar rainfall for the 24 June 2005 at 12:45 UTC. The white cross indicate Linkenholt site. The rain rate/h is indicated by the colour scale on the bottom left. The bullseye is centred at the Chilbolton radar with the first and second circles of radius 25 and $50 \mathrm{~km}$.

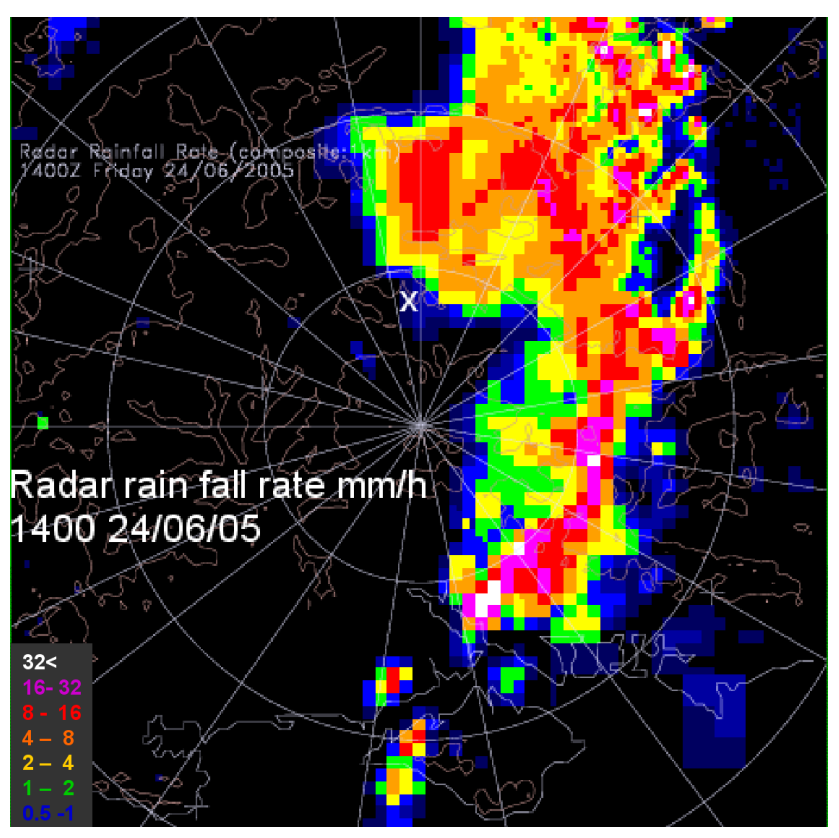

Fig. 5b. Composite weather radar rainfall for the 24 June 2005 at 10:00 UTC. The white cross indicate Linkenholt site. The rain rate/h is indicated by the colour scale on the bottom left. The bullseye is centred at the Chilbolton radar with the first and second circles of radius 25 and $50 \mathrm{~km}$.

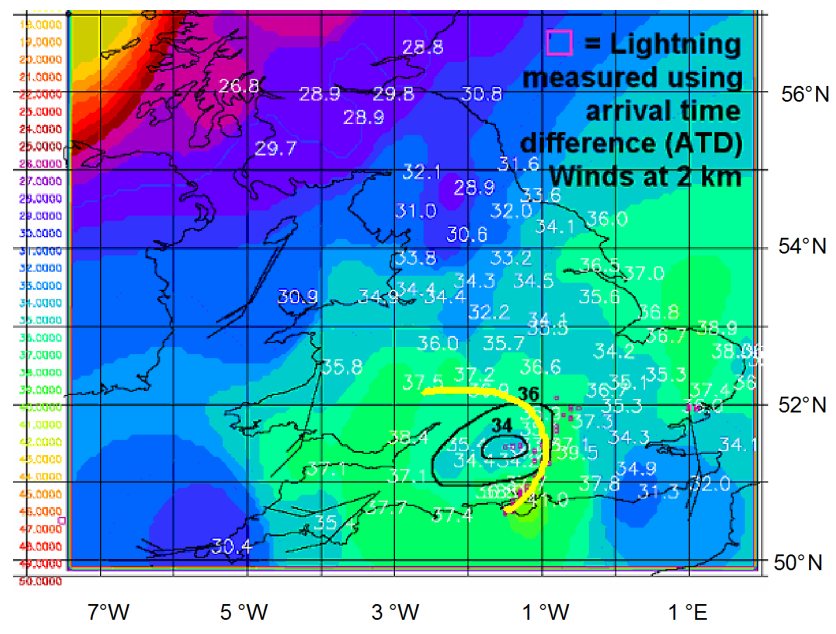

Fig. 6. GPS integrated water vapour processed by the Met Office/University of Nottingham system, 24 June 2005, 14:00 UTC. Contours give values of IWV in $\mathrm{kg} \mathrm{m}^{-2}$. Linkenholt is located at the edge of the lightning location at the centre of the $34 \mathrm{~kg} \mathrm{~m}^{-2}$ contouring. The yellow band indicates the arc of weather radar echo that seems to be associated with the band of lightning in the south.

area. Figure $5 \mathrm{a}, \mathrm{b}$ shows radar rain rate at 12:45 UTC and 14:00 UTC on 24 June 2005. At 12:45 UTC lightning strikes were associated with the rainfall cell to the northwest of Linkenholt and mostly with the line of activity stretching out over the sea from about $25 \mathrm{~km}$ south of Chilbolton. Here the activity was aligned essentially north south. At 14:00 UTC the area of lightning activity near Linkenholt had moved further east than in the south over the coast so a line of activity stretched south from east of Chilbolton to the coast and within $15 \mathrm{~min}$ the southern half of this line had intensified into a very intense storm. Lightning strikes occurred near Linkenholt both in the intense small low level cells furthest east in Fig. $5 \mathrm{~b}$ and in the less heavy rain to the east and north east of Linkenholt.

At 14:00 UTC the rain was just clearing above Linkenholt. The IWV calculated by the UK GPS network for the 24 June 2005 at 14:00 UTC is shown in Fig. 6. This shows a pool with lower IWV to the west of the convective storm, with measurements lower than $34 \mathrm{~kg} \mathrm{~m}^{-2}$, whereas in the part of the storm close to the line of lightning activity the measurements were close to $40 \mathrm{~kg} \mathrm{~m}^{-2}$. The microwave radiometer showed values of about $40 \mathrm{~kg} \mathrm{~m}^{-2}$ between 13:20 UTC and 13:50 UTC which then dropped very rapidly to $31.8 \mathrm{~kg} \mathrm{~m}^{-2}$ by 14:06 UTC, remaining at this value for about $20 \mathrm{~min}$. As the storm system moved east the minimum value of integrated water vapour fell further to a minimum of about $30 \mathrm{~kg} \mathrm{~m}^{-2}$ about $20 \mathrm{~km}$ to the north of Linkenholt. Figure 7 shows the measurements by the microwave radiometer from 13:00 UTC until 16:00 UTC, as the storm line passed over Linkenholt between 13:20 and 14:00 UTC followed by the driest air for the next $40 \mathrm{~min}$. When it was raining heavily 
between 13:20 and 13:40 UTC, the radiometer measurements should not be treated as fully reliable, but the structure following 14:00 UTC should be of good quality. The measurements from the infrared radiometer, Fig. 7, support the idea that the cloud base during the heavy rain had a temperature close to $21^{\circ} \mathrm{C}$ as indicated in the temperature inversion reported by the microwave radiometer at about $500 \mathrm{~m}$ above the ground, and that this reduced below $20^{\circ} \mathrm{C}$ in the dry air behind the rain. The inversion disappeared at 14:40 UTC, when the middle level cloud disappeared, as indicated by the infrared radiometer. Most of the lower troposphere above the inversion cooled with time during this period. Before the storm the surface temperature at Linkenholt was about $19.1^{\circ} \mathrm{C}$, and this fell from 12:40 UTC until it reached $15.4^{\circ} \mathrm{C}$ at 14:00 UTC and then gradually recovered back to about $19.6^{\circ} \mathrm{C}$ at 15:00 UTC. The radiometer indicated a shallow cool moist layer near the surface from 13:20 UTC onwards again probably due to evaporative cooling into drier air, leading to a temperature inversion at the surface (Fig. 7).

Plots of the winds and signal to noise ratio with time measured by the wind profiler at from 12:00-16:00 UTC are shown in Fig. 8a to c. Before the storm commenced at 12:00 UTC the winds near $500 \mathrm{~m}$ at Linkenholt were about $2 \mathrm{~m} \mathrm{~s}^{-1}$ from the north, whilst at $1 \mathrm{~km}$ were about $6 \mathrm{~m} \mathrm{~s}^{-1}$ from just south of east and at $2 \mathrm{~km}$ about $10 \mathrm{~m} \mathrm{~s}^{-1}$ from the south. This layer of easterly winds overlaid by southerly winds was present across much of southern England at this time.

The depth of the layer near the surface with a northerly wind component increased to about $1.5 \mathrm{~km}$ at 13:00 UTC and then dropped to about 500 $\mathrm{m}$ at 13:40 UTC. During the period from 13:15 UTC onwards the u component above $1.5 \mathrm{~km}$ increased to about $15 \mathrm{~m} \mathrm{~s}^{-1}$, which suggested that at this level the air was moving at a similar speed to the rain cells in the east west direction, whereas after 13:30 UTC the air between the surface and $700 \mathrm{~m}$ had an easterly component and was flowing at a relatively fast speed away from the thunderstorm activity. The driest air behind the storm was located between 0.8 and $1.8 \mathrm{~km}$ according to the radiometer, and the wind measurements between 13:40 and 14:00 UTC suggest that the dry air was being fed northwards into the system by the relative maximum in $v$ component between 1.2 and $2.2 \mathrm{~km}$ seen from 13:40 UTC onwards, with the air near the surface being left behind as an outflow from the system, having been cooled as water evaporated into the dry air at the interface between the dry air and the precipitation. As the dry air interacted with the convection it would have been moistened from above, so the drier air at the end of the precipitation is located at lower than in the dry air behind the system. The presence of the positive wind shear in the $v$ component suggests that there was a temperature gradient in the east west direction around $1 \mathrm{~km}$ with cooler air to the west from 13:40 UTC onwards, but unfortunately how long this persisted into the dry air behind the activity cannot be judged. The signals greyed out after 14:00 UTC were again
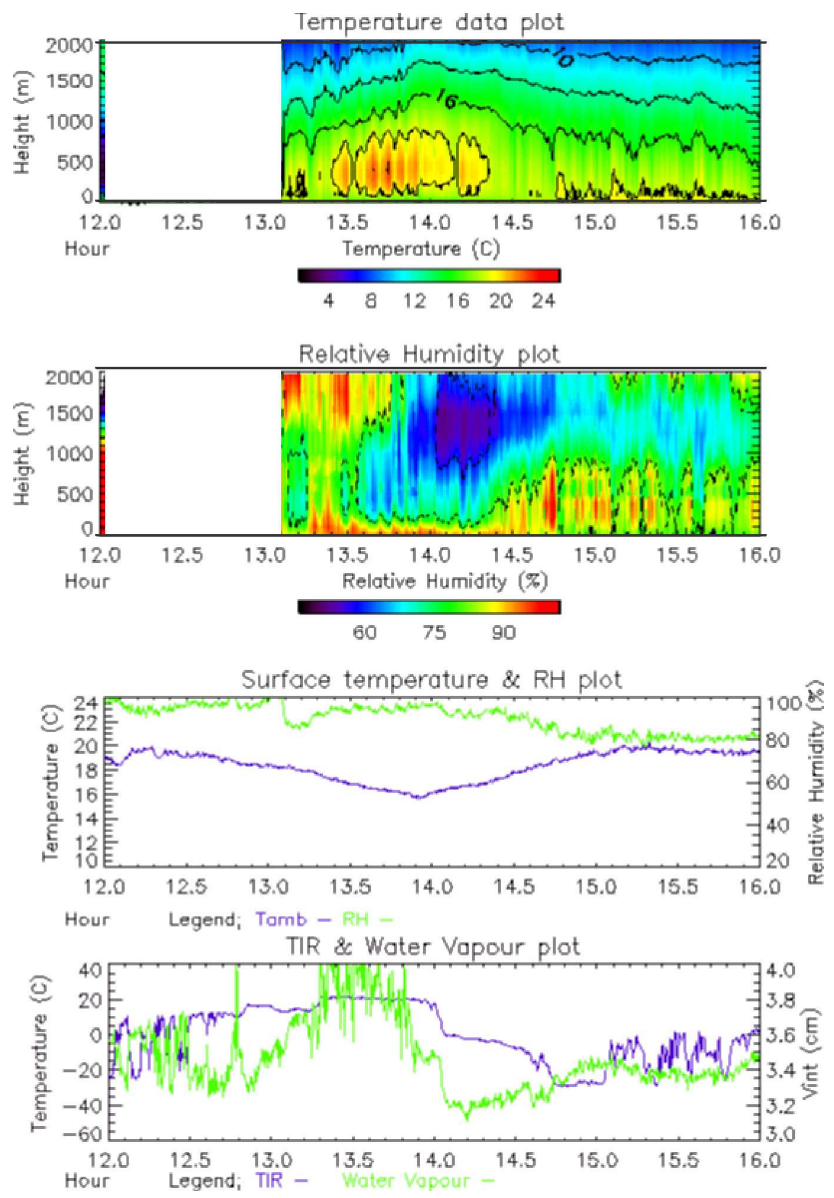

Fig. 7. Microwave radiometer retrieval showing temperature, relative humidity and for 0-2 km height, 24 June 2005, 12:0016:00 UTC. Radiometer calibration in error from 12:00 to 13:00, and radiometer measurements should be ignored in this period. Time series of scalars are also shown surface temperature and surface relative humidity, infrared brightness temperature, and integrated water vapour.

caused by range aliasing with weak signals near the ground being dominated by very strong signals from precipitation from higher up (above $7 \mathrm{~km}$ ), but being reported between $0-3 \mathrm{~km}$. The range aliasing was readily identified because the winds (horizontal and vertical) reported were far too high to have originated between 0 and $3 \mathrm{~km}$ on this day. Confirmation of large amounts of cloud at upper levels with dry air underneath following the line of storms can be seen from the cloud radar located at Chilbolton ( $20 \mathrm{~km}$ south) at about 14:00 UTC, where the upper cloud extends from 5 to $11 \mathrm{~km}$ (Fig. 9).

In general, the top of the convective boundary layer is characterised by an enhanced wind profiler signal (here plotted as $c_{n}^{2}$ derived from range normalised signal to noise) which corresponds to the temperature inversion which caps the convective layer and is often associated with a hydrolapse. The decrease of signal just above the convective 


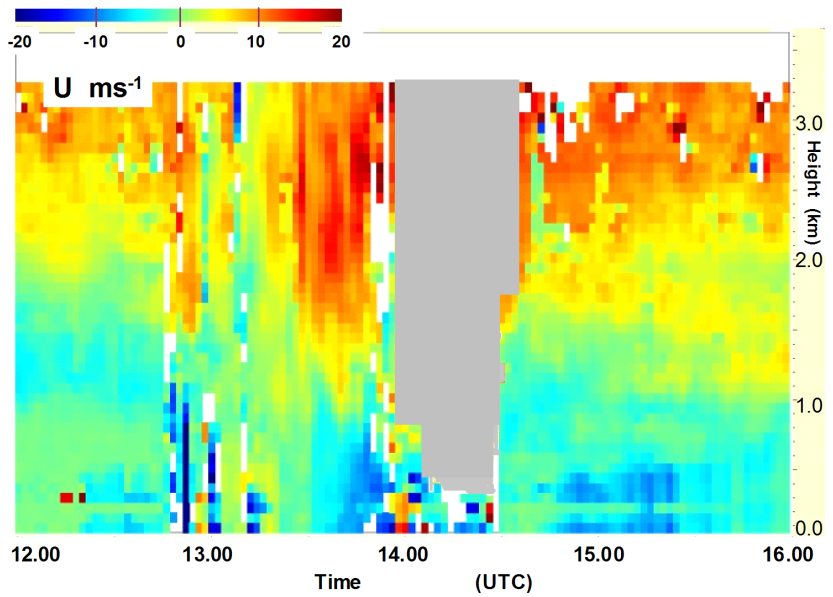

Fig. 8a. Wind $U$ component measured by the wind profiler at Linkenholt 24 June 2005, 12:00 to 16:00 UTC from 75 to $3250 \mathrm{~m}$ a.g.1., doubtful measurements are greyed out.

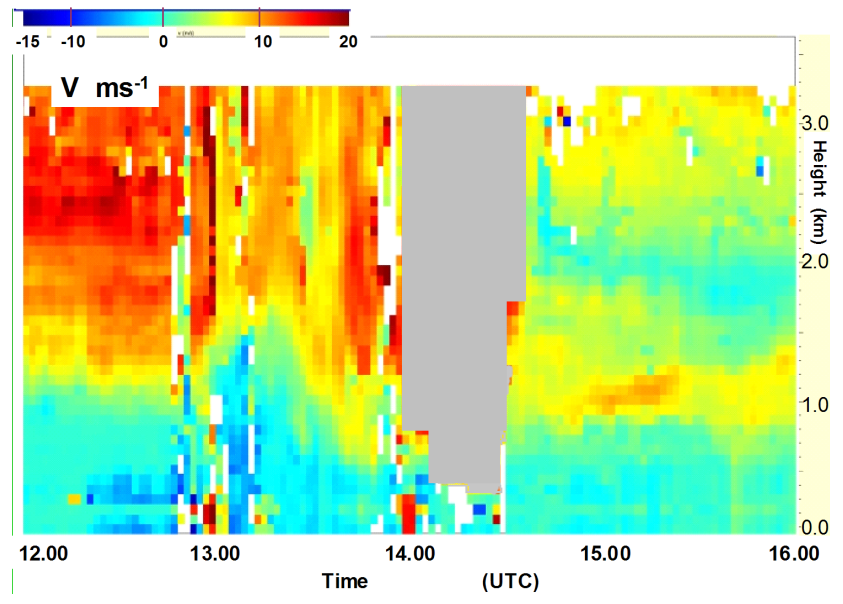

Fig. 8b. Wind $V$ component measured by the wind profiler at Linkenholt 24 June 2005, 12:00 to 16:00 UTC from 75 to $3250 \mathrm{~m}$ a.g.l., doubtful measurements are greyed out.

boundary layer is due to less turbulence in the free atmosphere, (Bianco, 2002). On this example, the top of the boundary layer is shown by the black line in Fig. 8c. This had collapsed earlier due to the cold pool generated by evaporation of rain into the dry air behind the thunderstorms. The boundary layer then increased in height from 14:30 UTC onwards, as the surface warmed by solar heating.

So in the afternoon the dry, cold air behind the storm was organised on a horizontal scale of about $100 \mathrm{~km}$ (see the weather radar arc associated with the activity in Fig. 6), which was a little less than the dimensions of the line of thunderstorms. The supply of drier air appears associated with a downdraught formed via drag and evaporation of the precipitation in the line of thunderstorms.

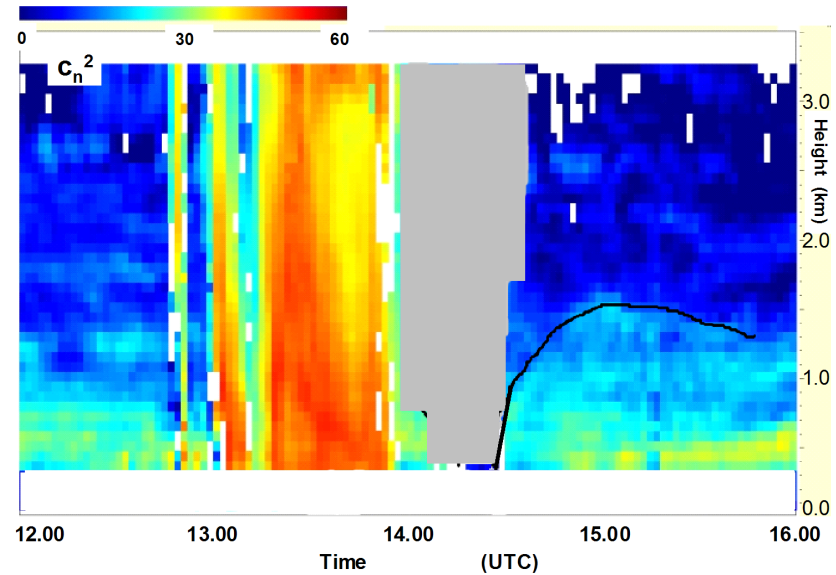

Fig. 8c. Range corrected signal to noise ratio measured by the wind profiler at Linkenholt 24 June 2005, 12:00-16:00 UTC. The estimated top of the boundary layer is marked with a black line.

Thus it can be seen that the combination of remote sensing observing systems can be used to sense organisation on scales of about $100 \mathrm{~km}$ as well as the very detailed information associated with individual small scale storms. The actual collapse of the boundary layer cannot be clearly seen from the wind profiler measurements in Fig. 8c, because of the range aliasing.

\subsection{Characteristics of cold pool associated with a develop- ing thunderstorm}

On 25 August 2005, a developing thunderstorm, centred to the south, passed close to Linkenholt, see the weather radar picture at 12:00 UTC in Fig. 10d. The winds were a little stronger, the air colder, and two groups of showers were followed by cold pools followed by an area of drier air about $70 \mathrm{~km}$ wide centred about $30 \mathrm{~km}$ to the south of Linkenholt, feeding into the storms. The evidence for the very stable conditions in the cold pools following the rain on this day can be seen in the signal to noise plots from the wind profiler in Fig. 10a. The stronger signals associated with the top of the boundary layer build up to over $1000 \mathrm{~m}$ from 08:30 UTC onwards. The vertical bands of strong signals from 10:40 UTC to just after 11:00 UTC and 12:00 to 12:15 UTC come from falling precipitation. After each of these events the top of the boundary layer has clearly fallen to $500 \mathrm{~m}$ or lower, and can be seen to recover to over $1000 \mathrm{~m}$ by 13:00 UTC. Figure $10 \mathrm{~b}$ shows the microwave radiometer measurements of surface temperature and integrated water vapour during this period. After the first shower, the temperature cooled at the surface from near $16^{\circ} \mathrm{C}$ to about $12^{\circ} \mathrm{C}$, and the radiometer shows cooling in the lowest $200 \mathrm{~m}$ of the atmosphere of similar magnitude This shower, located about $50 \mathrm{~km}$ east of Chilbolton at 12:00 UTC, developed into a short lived thunderstorm in the following hour. After the second shower, 


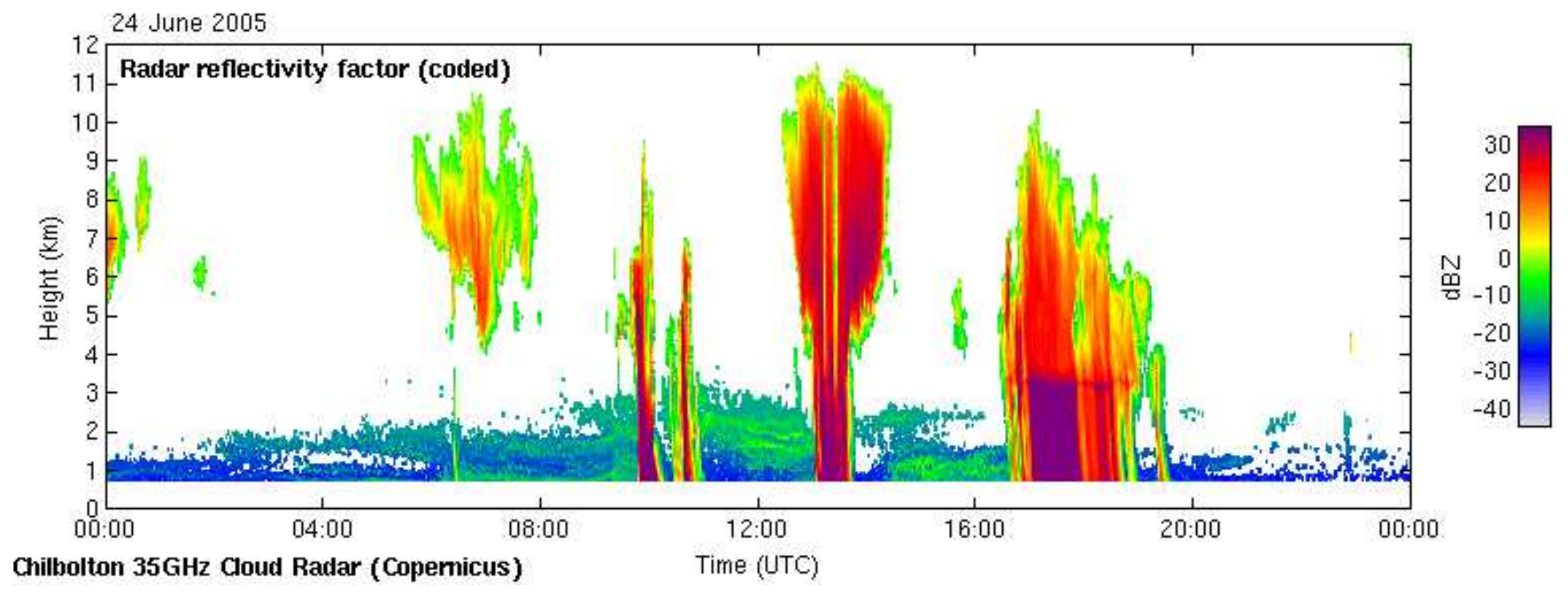

Fig. 9. Time height cross section of reflectivity measured the $35 \mathrm{GHz}$ cloud radar at Chilbolton. (from cloudnet website: www.met.rdg.ac. uk/radar/cloudnet/).

seen near Linkenholt in Fig. 10d, the surface temperature cooled to about $11^{\circ} \mathrm{C}$ and following the shower the IWV fell very rapidly to $14 \mathrm{~kg} \mathrm{~m}^{-2}$ (maximum values of IWV preceding the main part of the shower were about $20 \mathrm{~kg} \mathrm{~m}^{-2}$, see IWV contours in Fig. 10d). The pool of cold air near the surface (surface temperature lower than $12^{\circ} \mathrm{C}$ ) was observed by CSIP surface measurements, and seemed to stretch for about $50 \mathrm{~km}$ behind the first shower. The cold pool shown in Fig. 10d covered the area where measurements were available. A radiosonde measurement on the south coast near $2^{\circ} \mathrm{W}$ showed evidence of cooling of a depth of $250 \mathrm{~m}$ at 13:00 UTC, probably following another local shower. In Fig. 10c the microwave radiometer shows that the drier air behind the shower was located between 0.2 and $2 \mathrm{~km}$.

\section{Convective thermals}

On 29 June isolated thunderstorms occurred about 50 to $80 \mathrm{~km}$ north and northeast of Linkenholt, organising into a line to the northeast for just over $20 \mathrm{~min}$ from 15:00 UTC. CSIP analyses of the initiation of the thunderstorms this day concluded that the storms started once high level cloud cover moved away from central and southern England. The cloud to ground lightning strike activity started at about 13:45 UTC, with the nearest storm causing a flash flood at Oxford.

Figure 11a shows the time height evolution of the temperature profile measured by the radiometer between the surface and $1000 \mathrm{~m}$ between 13:00 UTC and 19:00 UTC. This period of time is characterised by a succession of unstable then stable condition near the surface, with two typical vertical profiles from the start of the period shown in Fig. 12. The unstable profiles (super-adiabatic) are associated with higher surface temperature than the more stable profiles which have lower dew point and hence mixing ratio. This may be the results of entrainment of air from above the boundary layer, e.g. see Couvreux et al. (2007).

Low cloud, cloud base at about $900 \mathrm{~m}$, moved across Linkenholt from time to time during the afternoon, as shown by the infrared temperature increasing from -40 to $+12^{\circ} \mathrm{C}$ eight times in the observing period, with the lower surface temperatures often correlated with the presence of low cloud, but not always. Thus shadowing by the cloud would have influenced the surface temperatures, and thus the convective conditions in the boundary layer. The oscillation in the surface temperature shows a periodicity of about $20 \mathrm{~min}$; see Fig. 11d, but the variations in surface temperature stop after 16:30 UTC, when the radiometer measurements indicate a change to higher stability in the typical vertical profiles of temperature and relative humidity. The network of GPS water vapour measurements indicated that air with higher integrated water vapour amounts(originally near the coast) had moved northwards over Linkenholt by 18:30 UTC. The drier air observed between 14:00 and 16:00 UTC, see Fig. 11b, seemed localised to the area near Linkenholt, and with the integrated water vapour increasing with time as the air moved northwards from Linkenholt towards the thunderstorms. Thus, the conditions observed at Linkenholt were too dry for most of the afternoon to trigger deep convection, but the moistening of the boundary layer further north near the river Thames then allowed the deeper convection to initiate.

The time series of the wind profiler signal to $c_{n}^{2}$ on this day, see Fig. 13, shows a local maximum in the vertical near the top of the boundary layer for most of the time. This fluctuated up and down between about $0.9 \mathrm{~km}$ and $1.5 \mathrm{~km}$ between 11:00 and 12:30 UTC, dropped lower between 12:30 and 13:30 UTC as the upper cloud passed and then fluctuated up and down between 0.8 and $1.5 \mathrm{~km}$ from 13:30 to 


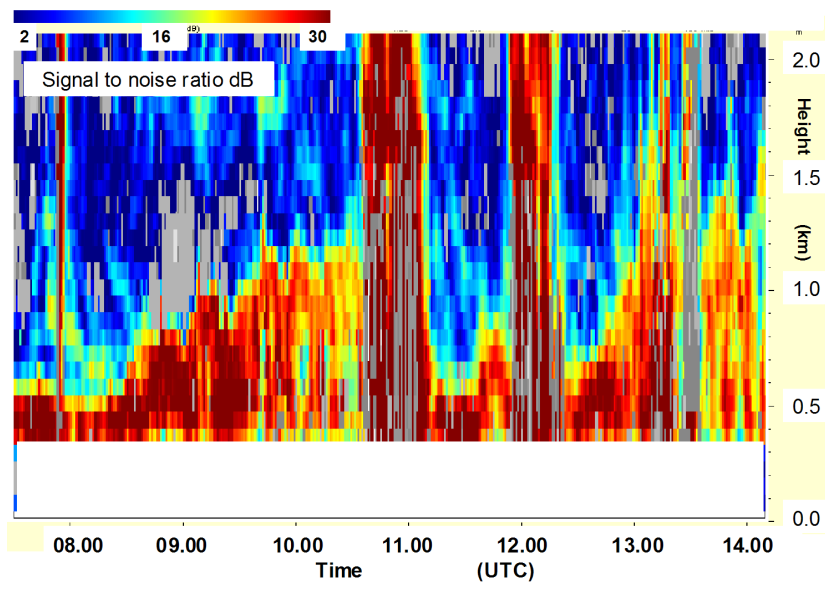

Fig. 10a. Signal to noise ratio measured by the wind profiler at Linkenholt 25 August 2005, 07:30-14:10 UTC from 75 to $2150 \mathrm{~m}$ a.g.1.
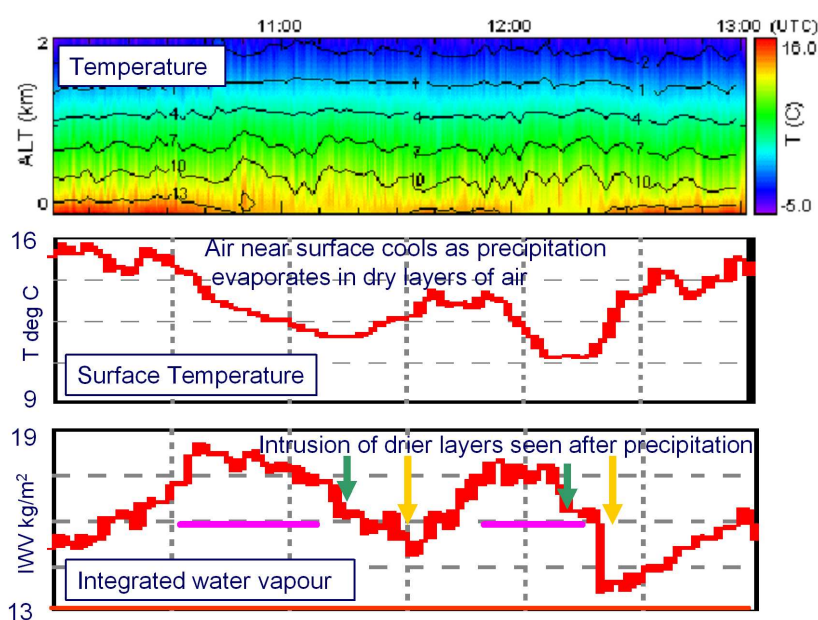

Fig. 10b. Microwave radiometer retrieval showing) temperature time-height cross sections for $0-2 \mathrm{~km}$ height, 25 August 2005, 10:00-13:00 UTC, plus time series of surface temperature, and integrated water vapour. Purple lines indicate regions where the radiometer liquid water measurements showed liquid water reaching the surface, the green arrows indicate where IWV first started to fall quickly (indicative of where cooling plus incomplete saturation of dry air caused IWV to fall) and yellow arrow where the driest air was first detected.

15:20 UTC and then between 1.1 to $1.9 \mathrm{~km}$ from $15: 20$ to about 17:00 UTC, after which the top of the boundary layer fell with time. The boundary layer was highest when cloud bases were detected at $900 \mathrm{~m}$ by the infrared sensor. Two radiosondes were launched from Larkhill during this period. The first at 12:00 UTC showed the top of boundary layer at about $1200 \mathrm{~m}$, with the mixing ratio of water dropping from greater than 7.9 in the boundary layer to $6.6 \mathrm{~g} / \mathrm{kg}$ at about $1.5 \mathrm{~km}$. The second at 15:00 UTC, showed the top of the

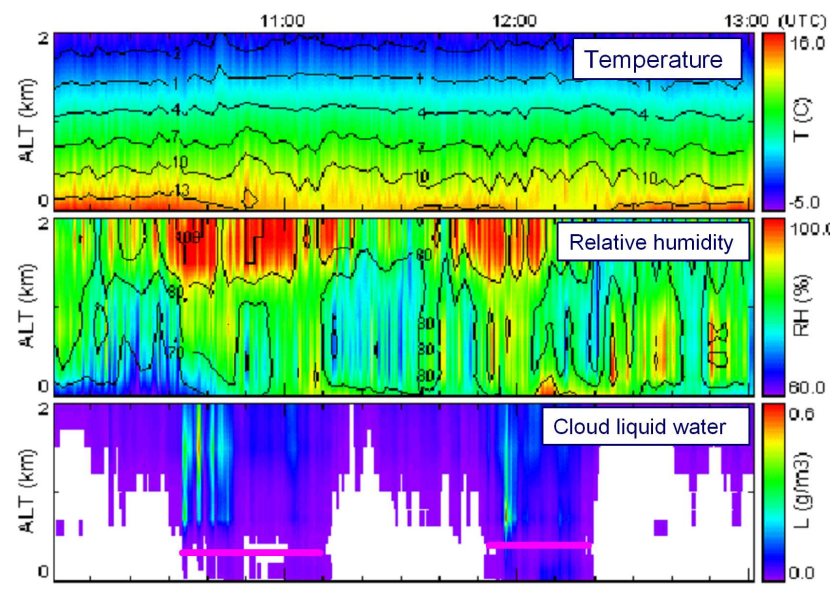

Fig. 10c. Microwave radiometer retrieval showing temperature, relative humidity and liquid water time-height cross sections for 0$2 \mathrm{~km}$ height, 25 August 2005, 10:00-13:00 UTC.

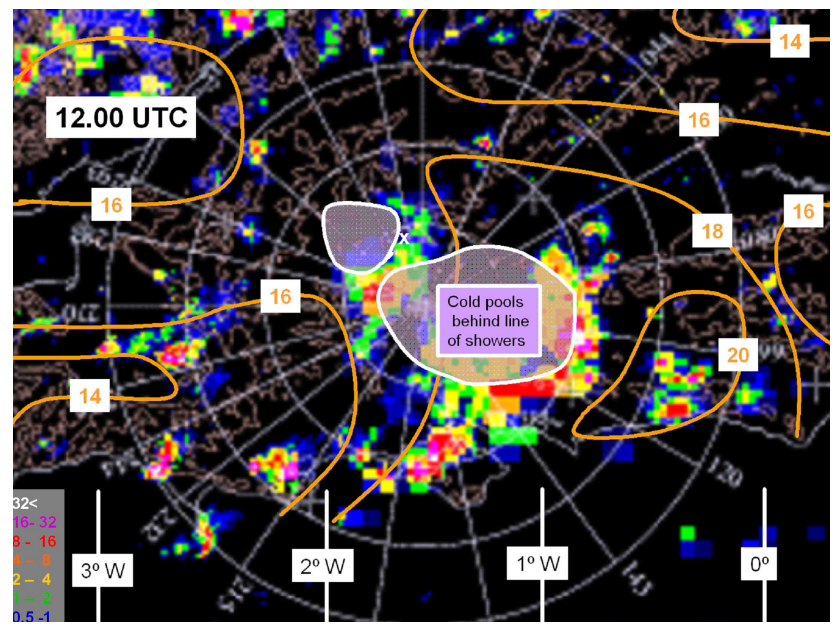

Fig. 10d. Composite weather radar rainfall for the 25 August 2005 at 12:00 UTC. The white cross indicates the Linkenholt site. The rain rate/h is indicated by the colour scale on the bottom left. The bulls-eye is centred at the Chilbolton radar with the first and second circles of radius 25 and $50 \mathrm{~km}$. Integrated water vapour contours are superimposed in orange at $2 \mathrm{~kg} \mathrm{~m}^{-2}$ intervals. The position of the cold pools of air close to the surface cooler than $12^{\circ} \mathrm{C}$ observed by the automatic weather stations deployed for CSIP are indicated by the white contours filled with light purple.

boundary layer at about $900 \mathrm{~m}$ with mixing ratios greater than $8 \mathrm{~g} / \mathrm{kg}$ in the boundary layer falling to values of $6.7 \mathrm{~g} / \mathrm{kg}$ at about $1.1 \mathrm{~km}$. The fluctuation in the top of the boundary layer in this manner (supported by the limited number of radiosondes) is considered typical of the boundary layer in the UK where convection was present in the boundary layer but not developing into deep convection over the site and entrainment was taking place into the boundary layer. 

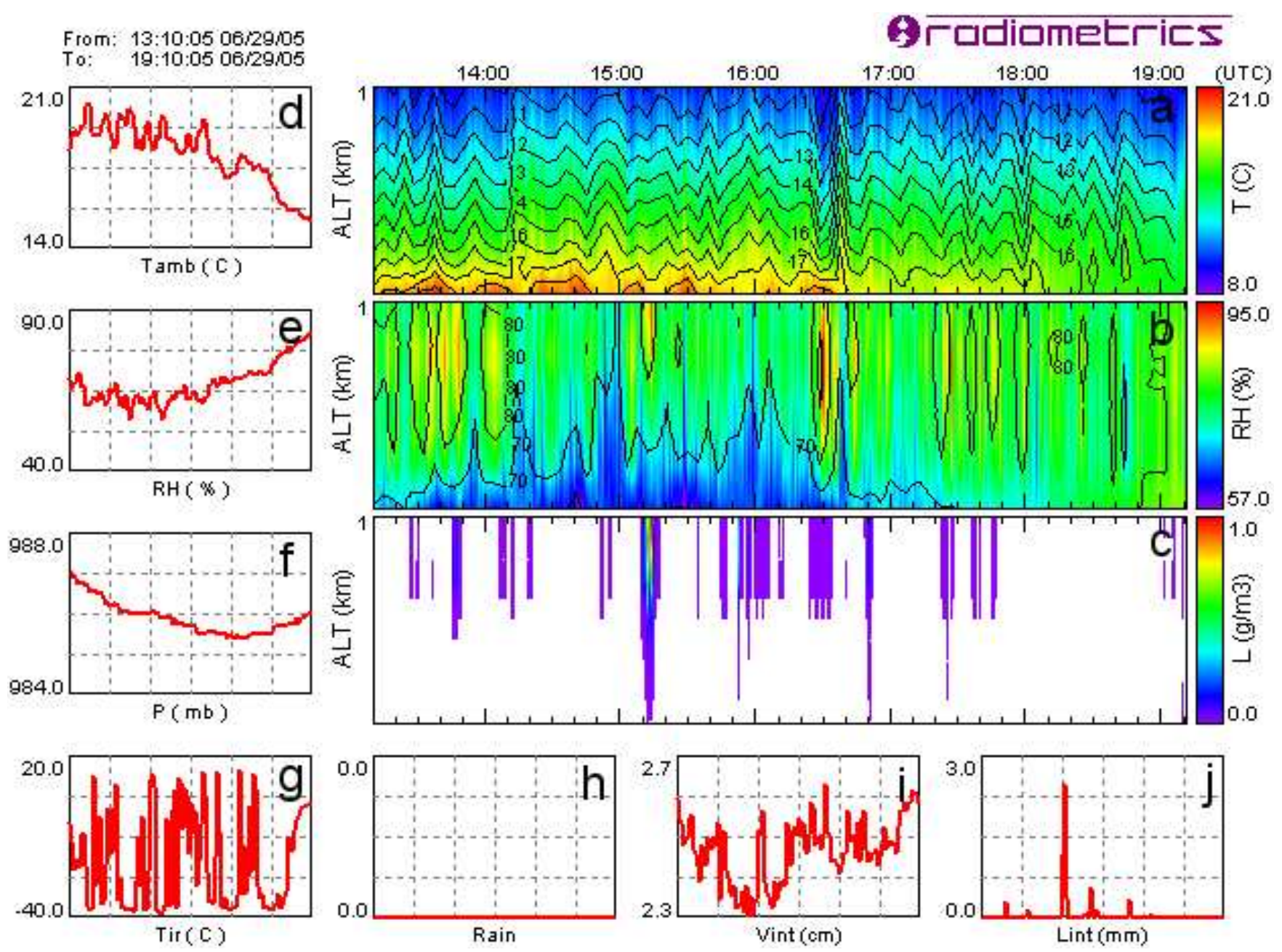

Fig. 11. Microwave radiometer retrieval showing (a) temperature, (b) relative humidity and (c) liquid water time-height cross sections for 0-1 km height, 29 June 2005, 13:10-19:10 UTC. Time series of scalars are also shown in red for (d) surface temperature, (e) surface relative humidity, (f) pressure, (g) infrared brightness temperature, (h) rain sensor, (i) integrated water vapour and (j) integrated liquid.

The succession of strong and low signals between 2 and $3 \mathrm{~km}$ does not coincide necessarily with the detection of cloud by the infrared radiometer, but the cloud detection between 13:00 and 16:00 UTC does correspond to the downdrafts in the vertical velocity measured by the wind profiler above $2 \mathrm{~km}$ in Fig. 14. The radiosonde measurements suggest that the clouds were most likely forming near $3 \mathrm{~km}$. Significant updrafts seem mostly limited to levels between 1 and $2 \mathrm{~km}$. This layer between 1 and $2 \mathrm{~km}$ was also the layer in which the $u$ and $v$ wind components were significant, with $u$ about $6 \mathrm{~ms}^{-1}$ above $1.2 \mathrm{~km}$ and $v$ about the same between 13:00 and 16:00 UTC dropping to about 3 or $4 \mathrm{~ms}^{-1}$ by 18:00 UTC. Winds within the boundary layer were lighter than this throughout this period. The updrafts and possible downdrafts observed were mostly located above the boundary layer. Ground clutter was a problem in the boundary layer and seems to have limited the ability to measure vertical velocity accurately in the lowest range gates. Apart from the downward vertical velocity in cloud, vertical velocities above $1 \mathrm{~km}$ were mostly updrafts from 13:00 to 15:00 UTC and insignificant after that.

Thus, the variations in signal to noise observed above the convective boundary layer were probably associated with cloud development, which was probably indirectly linked to the thermal activity in the convective boundary, with the variations and depth of the boundary layer falling after 17:30 UTC. Vertical velocities at all levels were small after 17:15 UTC.

The thermals in the convective boundary layer would be driven by heat transfer from the surface. It is probable that the temperature profile was unstable before the updraft starts, then fully mixed as the air lifts. If this was the case, an increase of 1 degree in the temperature profile at $950 \mathrm{hPa}$ was observed in the updraft, see Fig. 12. Here the later drier sounding corresponds to a time with vertical velocities downward from above the top of the boundary layer, so it is 


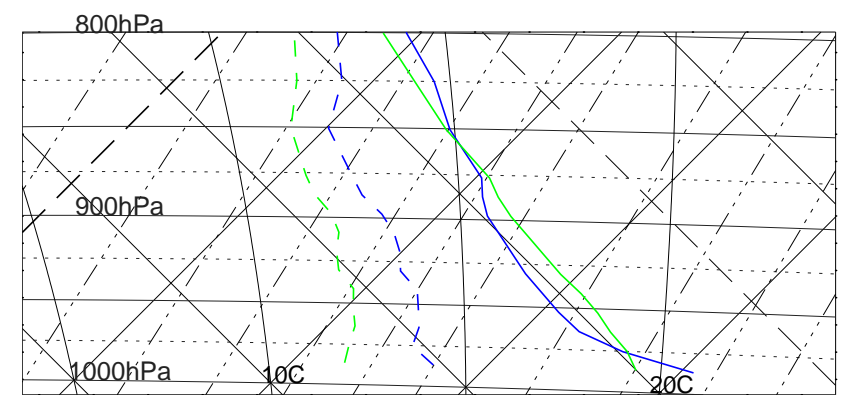

Fig. 12. Tephigram showing profile of temperature (solid line) and dew point (dashed line). Blue and green lines show the profile retrieved from the radiometer observation at Linkenholt, with a strong lapse rate near the surface at 13:32:42 UTC and more stable but drier conditions in the lowest $\mathrm{km}$ at 13:52:18 UTC. The dew point for the blue line corresponds closely to the radiosonde measurements at Larkhill at 12:00 and 15:00 UTC.

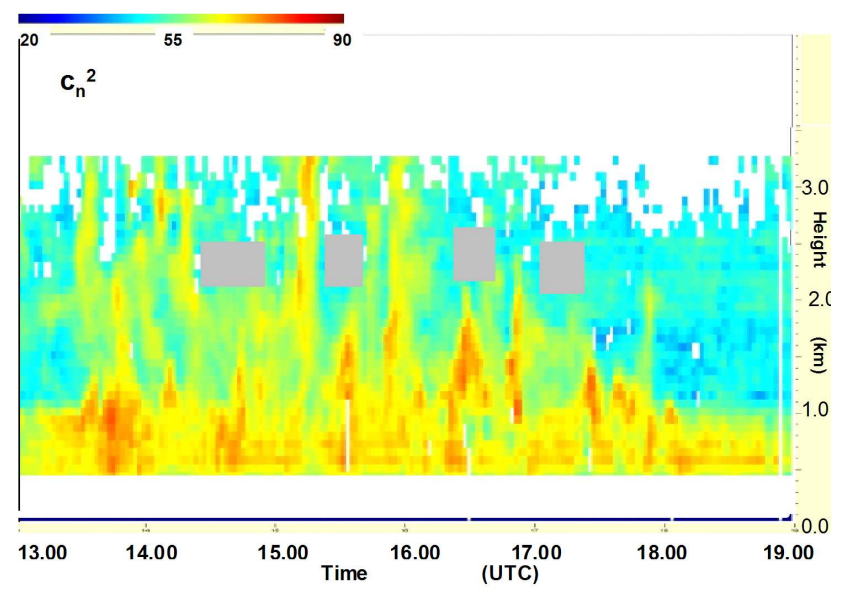

Fig. 13a. Range corrected signal to noise ratio measured by the wind profiler at Linkenholt 29 June 2005, 13:00-19:00 UTC form 75 to $3000 \mathrm{~m}$ a.g.l.

probable that the drier air is a result of entrainment from the layer above the top of the boundary layer.

An exact match with the temperature evolution seen by the radiometer and the wind profiler signal to noise and vertical velocity was not possible since the ground clutter contamination in the vertical beam prevented reliable measurement of the vertical velocity below about $800 \mathrm{~m}$.

On this day the radiometer and wind profiler show part of the vertical profile structures associated with cloud and boundary layer variation, full resolution of the conditions requires additional observing systems, such as laser ceilometer and cloud radar.

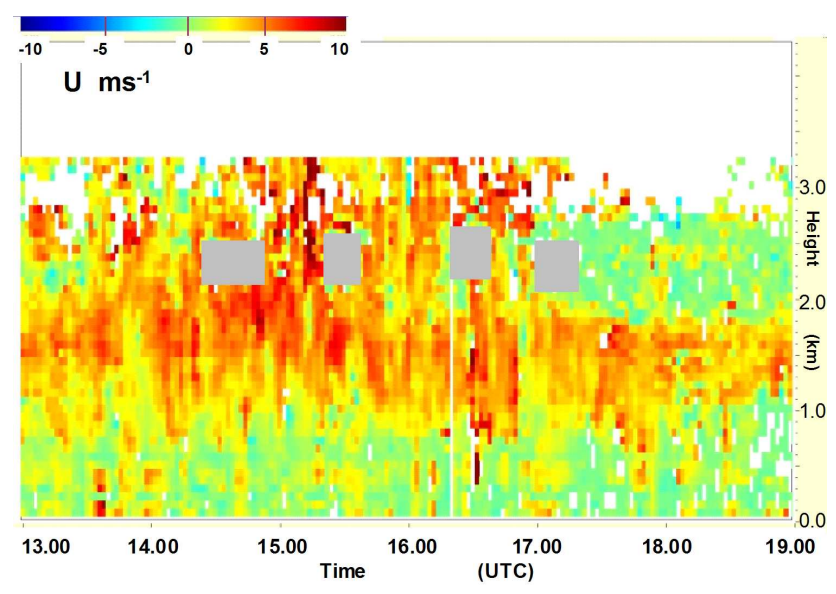

Fig. 13b. Wind $U$ component measured by the wind profiler at Linkenholt 29 June 2005, 13:00 to 19:00 UTC from 75 to $3250 \mathrm{~m}$ a.g.l., doubtful measurements are greyed out.

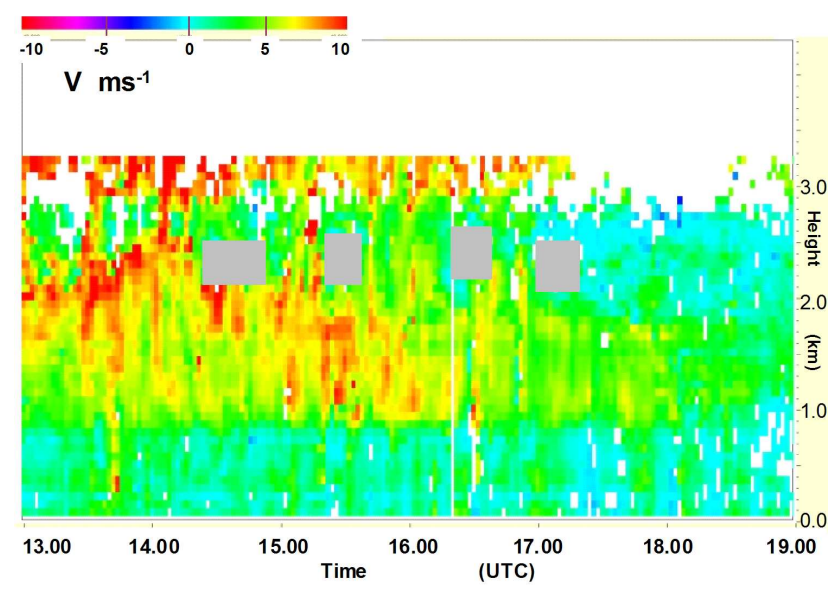

Fig. 13c. Wind $V$ component measured by the wind profiler at Linkenholt 29 June 2005, 13:00 to 19:00 UTC from 75 to $3250 \mathrm{~m}$ a.g.l., doubtful measurements are greyed out.

\section{Discussion and conclusion}

Ground based remote sensing instruments allow continuous monitoring of the lower troposphere. In this study, the instruments were used for the first time in preoperational experiments at very high time resolution to study short term variations in the boundary layer, given that conventional radiosonde observations rarely have a temporal resolution better than $6 \mathrm{~h}$.

The cooling of dry air in the boundary layer by rain evaporation plays a very important role in storm development. It can enhance or slow down their activity.

In the early morning on 24 June, a dry layer capped by a strong temperature inversion was strongly modified by rain evaporation probably by a combination of gust front and evaporation. In less than $10 \mathrm{~min}$ the amplitude of the 
temperature inversion was reduced by 2.5 degree. 5 min later the profile went back to its initial state. Such events can only be captured with high time resolution observing systems. 10 min later, the condition in the boundary layer changed permanently and convection near Linkenholt died out. In the afternoon the dimensions of a cold pool were clearly identified by the GPS network. The microwave radiometer observed changes of vertical structure within the drier air. Again in this case evaporation of rain from the thunderstorms cooled the dry air behind the storm. The effect of the rain evaporation cooling on the height of the convective boundary layer can be captured by using the wind profiler signal to noise ratio, and this can be used to validate vertical profiles produced by the microwave radiometer.

Modification of temperature inversions and increase of the humidity in the lowest level is quite important in initiation of deep convection. It is quite important to know where the evaporation takes place. If it effectively reduces the capping of the boundary layer, increased convection could occur, but if the evaporation takes place close to the surface or the cooled air descends to this level, it can create a temperature inversion, as seen in the afternoon of 24 June after the storms, which might limit the extent of the convection.

Variations in low level thermal structure were captured on 29 June, by the radiometer and surface measurements. This was possible because of the high time resolution of the microwave radiometer. Combining this information with the wind profiler measurements shows that updraft and downdraft were present. However it was not really possible to match the oscillation of the temperature with the vertical motion observed because the vertical beam of this wind profiler was strongly contaminated by ground clutter. Choosing a suitable site for equipment for this type of experiment is critical and needs to be done well in advance.

The combination of weather radar, radiometer, wind profiler, GPS sensors allowed us to follow 2 important mechanisms: latent heat exchange and thermal mixing. However, care has to be taken when interpreting radiometer results as they have limited vertical resolution. A modification close to the surface might propagate to a higher level because of the limited resolution. So further investigation and verification of this type of observation will be required, possibly using optical lidars to measure the vertical velocity in the boundary layer. While the wind profiler provides wind measurement very close to the surface, the Doppler spectra need to be checked to eliminate spurious signals, especially in the first $280 \mathrm{~m}$ above the surface. In this experiment the wind profiler was heavily contaminated by ground clutter, so the vertical speed was difficult to estimate. But the examination of data at high time resolution does allow us to identify updraft and downdraft between 1 and $2 \mathrm{~km}$. Such motions are not detectable in operational wind profiler modes when a half-hour consensus average is applied to the measurements. So, operational implementation of higher resolution measurements will require improved quality control of

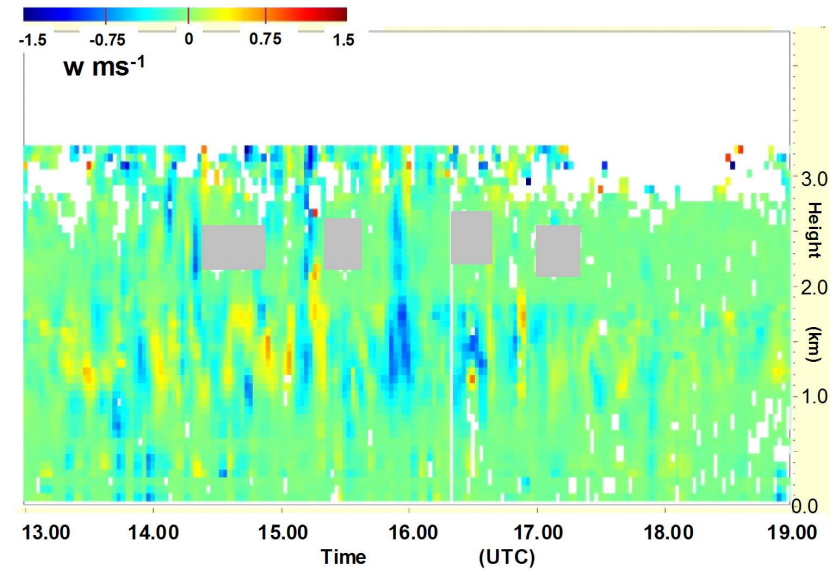

Fig. 14. Vertical speed measured by the wind profiler form the vertical beam at Linkenholt 29 June 2005, 13:00-19:00 UTC form $75 \mathrm{~m}$ to $3000 \mathrm{~m}$ a.g.1., the color scale goes from $-150 \mathrm{~cm} / \mathrm{s}$ to $+150 \mathrm{~cm} / \mathrm{s}$.

the observations, with the quality checking that has been performed manually in this study, automated as far as possible.

The combination of all these instruments at high time resolution is promising. The Met Office is currently in the process of upgrading its upper air observation network to meet some of the needs of high resolution numerical model $(1.5 \mathrm{~km})$. In that context test bed experiment are planned in the southern of UK in 2008. More instrumentation will be deployed on one site than used at CSIP, including cloud radar, a ceilometer, possibly a Doppler wind finding lidar, a radiometer and a wind profiler. The collocation of all the instruments should allow us to produce a fuller characterisation of some of the fundamental processes affecting the boundary layer, and then to optimise affordable operational observing systems for the future. It will also provide a chance to develop data assimilation procedures to utilise the information in future.

Acknowledgements. Topical Editor U.-P. Hoppe thanks two anonymous referees for their help in evaluating this paper.

\section{References}

Bevis, M., Businger, S., Herring, T. A., Rocken, C., Anthes, R. A., and Ware, R. H.: GPS meteorology: Remote sensing of atmospheric water vapor using the global positioning system, J. Geophys. Res., 97, 15 787-15 801, 1992.

Bianco, L. and Wilczak, J. M.: Convective boundary layer mixing depth: Improved measurement by Doppler radar wind profiler using fuzzy logic, J. Atmos. Ocean. Technol., 19, 1745-1758, 2002.

Browning, K., Blyth, A., Clark, P., Corsmeier, U., Morcrette, C., Agnew, J., Bamber, D., Barthlott, C., Bennett, L., Beswick, K., Bitter, M., Bozier, K., Brooks, B., Collier, C., Cook, C., Davies, F., Deny, B., Engelhardt, M., Feuerle, T., Forbes, R., Gaffard, C., Gray, M., Hankers, R., Hewison, T., Huckle, R., Kalthoff, 
N., Khodayar, S., Kohler, M., Kraut, S., Kunz, M., Ladd, D., Lenfant, J., Marsham, J., McGregor, J., Nicol, J., Norton, E., Parker, D., Perry, F., Ramatschi, M., Ricketts, H., Roberts, N., Russell, A., Schulz, H., Slack, E., Vaughan, G., Waight, J., Watson, R., Webb, A., Wieser, A., and Zink, K.: The Convective Storm Initiation Project, B. Am. Meteorol. Soc., 88(12), 19391955, 2007.

Cadeddu, M. P., Peckham, G. E., and Gaffard, C.: The vertical resolution of a ground-based microwave radiometer analyzed through a multiresolution wavelet technique, IEEE Trans. Geosci. Rem. Sens., 40(3), 531-540, 2002.

Cimini, D., Hewison, T. J., Martin, L., Güldner, J., Gaffard, C., and Marzano, F.: Temperature and humidity profile retrievals from ground based microwave radiometers during TUC, Meteorologische Zeitschrift, 15, 45-56, 2006.

Collier, C. G.: Flash flood forecasting: What are the limits of predictability, Q. J. Roy. Meteorol. Soc, 133, 3-23, 2007.

Couvreux, F., Guichard, F., Masson, V., and Redelsperger, J.-L.: Negative water vapour skewness and dry tongues in the convective boundary layer, Observations and large-eddy simulation budget analysis, Bound. Lay. Meteorol., 123, 269-294, 2007.
Güldner, J. and Spankuch, D.: Remote sensing of the thermodynamic state of the atmospheric boundary layer by ground-based microwave radiometry, J. Atmos. Ocean. Technol., 75, 151-166, 2001.

Hewison, T. J.: Profiling temperature and humidity by ground based microwave radiometer, PHD, Department of Meteorology, University of Reading, UK, 2007.

Klaus, V., Bianco, L., Gaffard, C., Matabuena, M., and Hewison, T. J.: Combining UHF radar wind profiler and microwave radiometer for the estimation of atmospheric humidity profiles, Meteorologische Zeitschrift, 15, 87-98, 2006.

Lean, H. W. and Clarke, P.: The effect of changing resolution on mesoscale modelling of line convection and slantwise circulation in FASTEX IOP16, Q. J. Roy. Meteorol. Soc., 129, 189-209, 2003.

Solheim, F., Godwin, J., Westwater, E., Han, Y., Keihm, S., Marsh, K., and Ware, R.: Radiometric Profiling of Temperature, Water Vapor, and Cloud Liquid Water using Various Inversion Methods, Radio Sci., 33, 393-404, 1998.

Young, G. S.: Turbulence structure of the convective boundary layer Part II, Phoenix 78 aircraft observations of thermals and their environment, J. Atmos. Sci., 45, 727-735, 1988. 